\title{
Leverage over the Firm Life Cycle, Firm Growth, and Aggregate Fluctuations
}

\author{
Emin Dinlersoz, Sebnem Kalemli-Ozcan, \\ Henry Hyatt, and Veronika Penciakova
}

\section{Working Paper 2019-18 \\ September 2019}

\begin{abstract}
We study the leverage of U.S. firms over their life cycles and the connection between firm leverage, firm growth, and aggregate shocks. We construct a new dataset that combines private and public firms' balance sheets with firm-level data from U.S. Census Bureau's Longitudinal Business Database for the period 2005-12. Public and private firms exhibit different leverage dynamics over their life cycles. Firm age and size are systematically related to leverage for private firms but not for public firms. We show that private firms, but not public ones, deleveraged during the Great Recession and that this deleveraging is associated with a reduction in firm revenue and employment growth. Exploiting sectoral variation, we find that the leverage dynamics of firms is also relevant for aggregate fluctuations.
\end{abstract}

JEL classification: E23, G32

Key words: leverage, firm dynamics, firm growth, firm life-cycle, financial constraints, borrowing limits, short-term debt, aggregate shocks

https://doi.org/10.29338/wp2019-18

All results have been reviewed to ensure that no confidential information is disclosed. The authors thank the participants of the National Bureau of Economic Research's Capital Markets group at the 2018 Summer Institute for comments. The views expressed here are those of the authors and not necessarily those of the U.S. Census Bureau, the Federal Reserve Bank of Atlanta, or the Federal Reserve System. Any remaining errors are the authors' responsibility.

Please address questions regarding content to Emin Dinlersoz, Center for Economic Studies, U.S. Census Bureau, 4600 Silver Hill Road, Suitland, MD 20746, emin.m.dinlersoz@census.gov; Sebnem Kalemli-Ozcan, University of Maryland, CEPR, and NBER, Department of Economics, 4118D Tydings Hall, College Park, MD, 20742, kalemli@econ.umd.edu; Henry Hyatt, Center for Economic Studies, U.S. Census Bureau, 4600 Silver Hill Road, Suitland, MD 20746, henry.r.hyatt@census.gov; or Veronika Penciakova, Research Department, Federal Reserve Bank of Atlanta, 1000 Peachtree Street NE, Atlanta, GA 303094470, veronika.penciakova@atl.frb.org.

Federal Reserve Bank of Atlanta working papers, including revised versions, are available on the Atlanta Fed's website at www.frbatlanta.org. Click "Publications" and then "Working Papers." To receive e-mail notifications about new papers, use frbatlanta.org/forms/subscribe. 


\section{Introduction}

A great deal is known about the life-cycle dynamics and growth of U.S. firms, but how their growth is financed and its implications are far less understood. Much of what is known about U.S. firm financing pertains to publicly-listed companies. There is far less evidence on the debt and financing patterns of private firms, due to a lack of data that covers both their balance sheets and real outcomes. Yet, the behavior of these firms, which are relatively younger and smaller than the average listed firm, has important macroeconomic implications. Private firms account for over 70 percent of aggregate employment and over 55 percent of aggregate gross output. Further, private firms are more susceptible to the effects of financial shocks that impede lending and borrowing than their publicly-traded counterparts who have easier access to different forms of financing. ${ }^{1}$

This paper offers a new, more comprehensive picture of how firms finance their operations at different points in their life-cycle, and characterizes the relationship between firm financing, firm growth, and aggregate fluctuations. We construct a new dataset that links the balance sheets of both publicly-traded and privately-held firms with their real outcomes, such as employment and revenue. We refer to this new dataset as LOCUS - a combination of the U.S. Census Bureau's Longitudinal Business Database (LBD), "L", with balance sheet data of privately-held firms from Moody's Bureau van Dijk Orbis, " $\mathrm{O}$ ", and of publicly-listed firms from Standard \& Poor's Compustat, "C", for the United States, "US". The LOCUS dataset has three key features that enable us to better study the relationship between firm life-cycle characteristics, financial constraints, and growth: (i) it better represents the firm size distribution, (ii) contains information on both firm age and size, based on employment, and (iii) includes detailed balance sheet data for both publicly-listed and privately-held firms.

Theory implies that firms' need for and ability to attain external finance varies substantially with age and size. Therefore, to understand how firms finance their operations, we need to study firms across the age and size distribution. Importantly, how we measure size also matters. Employment is arguably a better measure of size than assets because depending on whether assets are measured as book value or market value, an asset-based size measure will

\footnotetext{
${ }^{1}$ As discussed in the data section, between 2005 and 2012, listed, non-financial firms accounted for around 25 percent of domestic employment and 46 percent of domestic gross output in the U.S. Using financial data for private non-financial firms in the United Kingdom, Zeltin-Jones and Shourideh (2016) document that private firms finance nearly 80 percent of their investment using financial markets compared to only 20 percent among listed firms, and private firms disproportionately account for the transmission of financial shocks to the economy.
} 
fluctuate more (or less) than an employment-based size measure even though the firm may not be growing or shrinking. Further, precisely those firms that rely on external finance are most vulnerable to credit shocks, such as the one that led to the Great Recession. Therefore, to understand how the economy responds to credit shocks, we need to study the financing and labor and product market outcomes of both financially constrained and unconstrained firms.

The LOCUS dataset allows us to first study how firms finance their operations by comparing the understudied dynamics of leverage for private firms with those of listed firms, which have been the focus of existing literature. We document patterns of firm leverage both in cross-section and over time, and as a function of the life-cycle characteristics of firms - typically proxied by firm age and employment. We then study the implications of these patterns in firm leverage for responsiveness to credit shocks and firm growth in the context of the financial crisis that led to the Great Recession. Finally, we exploit sectoral variation to explore the connection between leverage and aggregate fluctuations in employment and revenue before, during, and after the financial crisis.

First, our empirical analysis indicates extensive heterogeneity in leverage by firm age and size among private firms, conditional on firm-level observables associated with leverage. In the cross section of private firms, larger firms are more leveraged regardless of the maturity of the debt, and have less equity as a fraction of their assets. As private firms get older, leverage declines, both in terms of short-term and long-term debt, and their equity increases as a fraction of assets. Small private firms are the least leveraged, but young private firms are the most leveraged. Therefore, size and age have different relationships with leverage for private firms. The negative relationship between age and leverage is likely driven by firms starting out at a size that is below their efficient scale, which induces new firms to borrow more than older firms. Through a fixed effects panel analysis that exploits within-firm variation, we show that private firms become more leveraged in short-term debt as they grow, which further supports our interpretation. This result is noteworthy in view of the literature on publicly-traded firms that finds high persistence in leverage, which results in insignificant connection between leverage and key firm characteristics, such as collateral, profitability, and size, in firm fixed effects specifications (see, e.g., Lemmon, Roberts and Zender (2008).)

In stark contrast to private firms, the relationship between short-term leverage and size is weak and slightly negative in the cross-section of public firms. However, large public firms have higher leverage in terms of long-term debt. This compositional effect renders no system- 
atic relationship between total leverage and size for public firms. At the same time, equity-size relationship has an inverted U-shape for these firms. While public firms have access to external equity via stock issuances, their financing relies less on external equity and more on long-term debt as they become larger. Compared to private firms, the relationship between age and leverage is far weaker among public firms. Public firms also appear to slightly reduce their equity as they age. This pattern is consistent increasing long-term leverage for these firms as they grow older and become larger. The fixed effects specification suggests that firm size is not systematically related to short-term, long-term, or total leverage among public firms.

These results are interesting from the perspective of standard firm dynamics literature with financial frictions. The empirical firm dynamics literature has established that, conditional on age, firm growth is negatively related to firm size. In addition, conditional on size, firm growth is negatively related to firm age (e.g. Davis, Haltiwanger and Schuh (1996)). Benchmark models of firm dynamics, such as Jovanovic (1982) and Hopenhayn (1982), cannot account for these conditional dependencies. Cooley and Quadrini (2001) and Albuquerque and Hopenhayn (2004) show that adding financial frictions to these models can account for these conditional life-cycle dynamics. These models have different predictions on how much firms of different ages and sizes borrow, and why. In Cooley and Quadrini (2001) size and leverage are negatively associated, conditional on age and productivity, because smaller, younger, and more productive firms have higher leverage, and leverage declines over time as firms increase their equity. In Albuquerque and Hopenhayn (2004), size and leverage are positively associated because firms pay down the long-term debt they took up to finance an initial investment and build up equity over time, which relaxes the constraint on short-term borrowing. Therefore, as firms grow, they incur more short-term debt. Both of these models also predict a negative relation between age and leverage since young firms borrow more. ${ }^{2}$

Our next exercise is to exploit the cross-sectional heterogeneity in leverage across private firms, and test whether credit constraints differentially affect small firms and whether there are any aggreate implications of these dynamics. We use the Great Recession as a shock to financial conditions. Such a shock can worsen financial frictions for already constrained firms, and can also tighten borrowing constraints on previously unconstrained firms. Our analysis

\footnotetext{
${ }^{2}$ There are also other models of financial frictions such as Buera and Moll (2015), which assume that firms operate a constant returns-to-scale technology and have the same borrowing limit, and there is no heterogeneity in firm leverage by firm age and size.
} 
indicates that small private firms have lower leverage during the crisis. Larger private firms are also affected, and their leverage also declines. The short-term leverage-employment profile is steeper in the pre-crisis period than during the crisis. That is, the firm size differential in short-term leverage narrows during the crisis. Overall, some firms are likely credit constrained both in normal and crisis times (small private firms), some firms appear to become more constrained during the crisis times (large private firms), and some firms do not seem to be constrained at all (large public firms). ${ }^{3}$

We also study the impact of the Great Recession on credit access among private and public firms by exploiting within-firm variation. We differentiate between normal (2005-2007), crisis (2008-2009), and post-crisis (2010-2011) periods, and study how the strength of the relationship between size and leverage varies across these periods, separately for public and private firms. Doing so allows us to capture the differential response of private and public firms to the financial shock and recovery, and to verify whether our cross-sectional results hold within firms over time. Firm fixed-effects specifications condition on standard determinants of leverage, and account for firm-level demand conditions with profitability, sectoral shocks with sectoryear fixed affects, and local demand shocks with county-year fixed effects. We follow the literature that argues that demand shocks were local during hte Great Recession and the use of county-time fixed effects absorb these local demand shocks (e.g. Greenstone et al. (2015), Gilchrist et al. (2017).) Conditional on these controls, we interpret the remaining firm-level variation in the observed amount of borrowing stemming from variation in the maximum amount a firm can borrow (financial constraints), where this amount changes across firms of different sizes and ages, and responds to credit shocks. In this interpretation, the underlying identifying assumptions are (i) for a given firm size (or age) level, borrowing constraints are binding for some firms and the average leverage of firms is thus informative about the underlying borrowing constraints at that level, controlling for observables that influence firm demand for borrowing, and (ii) the financial shock of the Great Depression shifts the underlying borrowing constraints.

For private firms, we find a positive association between employment and short-term leverage before the crisis, consistent with our cross-sectional results. During and after the crisis

\footnotetext{
${ }^{3}$ Using financial data from the universe of firms in Canada, Huynh, Paligorova and Petrunia (2018) obtain results that are similar to our results for the U.S. They find that private firms have more leverage than public firms, driven by the fact that private firms rely more on short-term debt compared to public firms.
} 
this relationship becomes negative, which suggests that private firms underwent a process of deleveraging in response to the Great Recession. In contrast, for public firms there is in general a statistically insignificant connection between firm size and leverage during all periods. We then study the relationship between firm financing and real outcomes. We find that for private firms both revenue and employment growth are positively associated with leverage before the crisis. As firms deleverage, these relationships turn weaker in magnitude during the crisis, and fail to recover to their pre-crisis magnitudes during the post crisis-period. Once again, in the case of public firms, the growth-leverage relationship is not statistically significant for employment and revenue. These results indicate that the financial condition of a firm, summarized by its leverage, has a stronger connection to firm growth in the case of private firms and that this relationship is mitigated when these firms deleverage.

To study the connection between firms' leverage and aggregate outcomes, we exploit sectoral variation. Aggregating firm level data to the sector level, we analyze the relationships between sectoral leverage, on the one hand, and sector size and growth, on the other. The results indicate a positive pre-crisis relationship between sector size (employment or revenue) and short-term leverage. The relationship turns negative during the crisis, and stays negative in the post-crisis period. Moreover, sectoral employment growth also has a positive association with sectoral leverage during the pre-crisis period. This association weakens substantially during the crisis and becomes negative in the period following the crisis. Similar to the case of employment growth, the relationship between sectoral revenue growth and leverage is positive before the crisis, and it is negative during the crisis. However, the relationship becomes once again positive in the post-crisis period, unlike in the case for employment. Overall, these findings suggest that Great Recession may have induced potentially longer-lasting negative effects on employment in highly leveraged sectors, compared to revenue.

We proceed as follows. Section 2 reviews the literature. Section 3 describes the data, presents statistics on the share of aggregate US economic activity accounted by private firms, and addresses selection in the LOCUS dataset. Section 4 studies the relationship between firm leverage and key firm life-cycle indicators - age and employment. Section 5 exploits the Great Recession to analyze the impact of credit shocks on credit access. Section 6 assesses the relationship between leverage and firm growth, and section 7 explores the link between firms' leverage and aggregate outcomes. Section 8 concludes. 


\section{Literature}

We provide a brief survey of two strands of literature that our paper relates to. We start with the literature on how firm age and size relate to firm financing. We then review the literature on financial constraints and their firm-level and aggregate implications.

\subsection{Firm Financing and Life-Cycle Dynamics}

Given the heterogeneity observed in the data, we gain insights from the theoretical financial frictions literature featuring firm-level heterogeneity. Among the models that introduce heterogeneity in productivity among firms, some posit constant returns-to-scale technology and firms borrow as much as they can up to a limit. This is the case, for instance, in Moll (2014) and Buera and Moll (2015), where the ratio of debt to assets is constant among firms. Richer predictions on how borrowing behavior relates to firm size and age come from studies in which firms operate decreasing returns-to-scale technologies. For instance, Cooley and Quadrini (2001), Khan and Thomas (2013), and Crouzet and Mehrotra (2017) introduce financial frictions into models of industry dynamics. Decreasing returns to scale technology is also a common modeling choice in the entrepreneurship and occupational choice literature as in Cagetti and De Nardi (2006), Buera and Shin (2013), Bassetto, Cagetti and De Nardi (2015), and Dinlersoz, Hyatt and Janicki (2017). ${ }^{4}$ In most of these models, firms face a reduced-form, short-term (one-period) borrowing constraint, where borrowing is limited to some multiple of the entrepreneur's current capital or assets. The multiple can be a constant (e.g. Evans and Jovanovic (1989), Quadrini (2000), Cagetti and De Nardi (2006)), or a more general function of the firm's productivity or capital stock (e.g. Virgiliu and Xu (2014), Khan and Thomas (2013)). ${ }^{5}$

Decreasing returns to scale implies that firms have an optimal size, and as firms approach this size over time, the incentive to borrow and the amount borrowed as a fraction of firm's assets naturally lessens. ${ }^{6}$ A natural prediction of these models is that firm leverage should be

\footnotetext{
${ }^{4}$ While some models assume all firms employ a decreasing returns to scale technology, models such as Cagetti and De Nardi (2006), Bassetto et al. (2015), and Dinlersoz et al. (2017) distinguish between an entrepreneurial sector in which firms are operated by households using a decreasing returns to scale technology, and a corporate sector which is characterized by a constant returns to scale technology. In these models, financial constraints apply only to the entrepreneurial sector.

${ }^{5}$ In Gopinath, Kalemli-Ozcan, Karabarbounis and Villegas-Sanchez (2017), although firms operate under CRS, the limit on borrowing is a convex function of firm's capital, implying that the constraint on borrowing relaxes as a firm grows, but at a decreasing rate. This model implies larger firms are more leveraged.

${ }^{6}$ In some of these models, there is an important distinction between the predictions on firm size uncondi-
} 
decreasing in age. ${ }^{7}$ Models with decreasing returns-to-scale technologies have more ambiguous predictions about how borrowing varies with firm size. In particular, the size-leverage relationship depends on the way that financial frictions are modeled. In Cooley and Quadrini (2001) financial frictions are modeled via default risk that is priced in an interest rate differential rather than a borrowing limit. Financial intermediaries share the costs of default, which in turn induces smaller, riskier businesses of any age to borrow more. However, when financial intermediaries choose the size of loans (i.e., have a borrowing limit that is endogenously determined) as in Albuquerque and Hopenhayn (2004), larger businesses may have a higher leverage ratio than smaller ones since they are further away from the exit threshold.

A smaller subset of studies on financial frictions endogeneize borrowing and distinguish between short-term and long-term debt, including Diamond (1991), Albuquerque and Hopenhayn (2004), and Alfaro, Bloom and Lin (2016). For instance, Albuquerque and Hopenhayn (2004) introduce an endogenous borrowing constrain that arises due to the limited enforcement of contracts between the firm and lender. The model features idiosyncratic revenue shocks that drive firm dynamics, and distinguishes between short-term and long-term debt. These features generate predictions regarding borrowing behavior by firm size and age. ${ }^{8}$ In particular, firms with prospects of better revenue shocks and growth opportunities are associated with higher initial debt, exhibit lower failure rates, pay off their long-term debt faster, and eliminate their short-term borrowing constraint quicker. At any point in time, larger firms have higher leverage and long-term debt, conditional on the revenue shock. As the equity of an entrepreneur grows, debt maturity changes - short-term debt increases relative to longterm debt. In general, short-term borrowing constraints relax as a firm grows, and firms can eventually overcome their reliance on external financing as they continue to pay off long-term debt and the accumulated equity becomes sufficient to finance the firm. Therefore, conditional on the size, older firms have lower debt; and, conditional on age, larger firms have higher debt.

tionally, and conditional on age. Because all firms start out small, the set of large firms contains many that have paid off their debts. Hence, borrowing declines in firm size as in Cooley and Quadrini (2001) (page 1296). But conditional on age, firms that borrow more are those that experience better productivity shocks.

${ }^{7} \mathrm{~A}$ similar approach is taken by Clementi and Hopenhayn (2006). In their framework like many others with a concave production technology, firms start with a large initial investment pay down their debts over time. However, heterogeneity among firms is beyond the scope of their study and so does not offer predictions of borrowing where size is conditional on age.

${ }^{8}$ Here, we note the model's general predictions. Albuquerque and Hopenhayn (2004) also specify a special case in which lenders coordinate on both the availability of credit and the borrowing limit, in which case overall debt can be written as a sequence of short-term contracts. In their more general case, a firm's level of long-term debt is given by an incentive compatible sequence of repayments that solve a recursively defined default problem. 
Using LOCUS, we assess whether the empirical evidence some of the key predictions of firm financing models.

Our paper also relates to the extensive empirical literature seeking to understand the determinants of listed firms' balance sheet structure and its effects on investment and hiring decisions. The seminal work of Rajan and Zingales (1995), using data on non-financial publicly listed firms in G-7 countries in the late 1980s, documents that size, profitability, and collateral are the most important determinants of firm leverage. More recently, Custodio, Ferreira and Laureano (2012) document a rising reliance on short-term debt among U.S. listed firms, particularly driven by small firms who face higher information asymmetry and choose to issue more public equity. Ajello (2016) finds that between 1989 and 2008, thirty-five percent of U.S. listed firms' investment is funded using financial markets. Similar to Ajello (2016), Covas and Den Haan (2012) show listed firms finance investment with both debt and equity, and that both forms of financing are more pro-cyclical for smaller listed firms. Begenau and Salomao (2015) find that while large firms are able to substitute between debt and equity over the business cycle, small firms' debt and equity are both procyclical. In this paper, we are able to provide new evidence on the importance of these determinants for privately held firms in the United States.

\subsection{Firm Financing and Firm and Aggregate Outcomes}

Firm-level borrowing constraints play a critical role in macroeconomic models featuring financial frictions and credit shocks. Building off contributions featuring a representative firm (Schliefer and Vishny (1992), Hart and Moore (1994), Holmstrom and Tirole (1997) , Kiyotaki and Moore (1997), Bernanke and Gilchrist (1999), Mendoza (2010), Jermann and Quadrini (2012), Brunnermeier and Sannikov (2014)), a complementary body of work in macroeconomics and corporate finance seeks to understand the heterogeneous effect of aggregate shocks, including credit tightening and contractionary monetary policy, on firm-level and aggregate sales, investment, and employment. Cooley, Marimon and Quadrini (2004), Khan and Thomas (2013), Gopinath et al. (2017), Quadrini (2000), Cagetti and De Nardi (2006), Dinlersoz et al. (2017) incorporate firm heterogeneity into models with borrowing constraints. These constraints play an important role in propagating aggregate shocks. The seminal work of Gertler and Gilchrist (1994) shows that the financial accelerator mechanism works via credit con- 
straints primarily for small firms. That is, adverse shocks are mainly propagated via small firms' borrowing constraint.

The empirical literature remains divided on the importance of heterogeneity in transmitting aggregate shocks. Focusing on heterogeneity in leverage, Ottonello and Winberry (2018) use high frequency identification of monetary policy shocks and Compustat data to show that highly leveraged firms are less responsive to monetary policy shocks, because of higher default risk. In contrast, Jeenas (2018), also using Compustat firms, finds that investment of highly leveraged firms is more responsive to monetary policy shocks. Similarly, matching listed firms from Compustat to their establishments in the LBD, Giroud and Mueller (2017) find that when house prices drop, employment falls significantly more in establishments belonging to more leveraged listed firms.

Other papers focus instead on heterogeneity in age and size. Several empirical papers using Compustat firms show a higher sensitivity of small firms to credit tightening measured by recessions or monetary policy tightening (e.g. Farre-Mensa and Ljungqvist (2016), Rajan and Zingales (1995), Whited and Wu (2006)). In contrast, Moscarini and Postel-Vinay (2012) use public data from the BDS and Kudlyak and Sanchez (2017) and Chari, Christiano and Kehoe (2013) use confidential data on a sample of private firms from Quarterly Financial Reports (QFR) survey to show that the employment, sales, inventories and short-term debt of large firms is more responsive to aggregate shocks. ${ }^{9}$ Using QFR data, Crouzet and Mehrotra (2017) find no differences in responsiveness of debt to aggregate shocks by firm size. Finally, papers that identify credit supply shocks directly show that small and young firms are more affected by such shocks (see, e.g., Chodorow-Reich (2014), Chodorow-Reich and Falato (2017), Gilchrist, Siemer and Zakrajsek (2018).)

Fort, Haltiwanger, Jarmin and Miranda (2013) note that much of this empirical literature does not adequately distinguish the roles of age and size. For instance, QFR contains small and large firms, but does not contain a measure of firm age. And Compustat contains firm age, but only includes relatively large and old firms, and measures firm employment using global operations rather than U.S. domestic employment. LOCUS overcomes both of these shortcomings and enables us to study the implications of heterogeneity in leverage, age, and size for firm growth and responsiveness to shocks. In doing so, we help inform the theoretical

\footnotetext{
${ }^{9}$ Chari et al. (2013) show that greater sensitivity of small firms is not robust to all time periods and in most recessions since 1950s the response of small and large firms were similar.
} 
literature on how credit shocks are propagated to the aggregate economy.

\section{Data}

To provide a more comprehensive picture of firm financing and its connection to firm and aggregate outcomes, a new database that incorporates financial, employment, and sales information for private firms is needed since U.S. listed firms account for only part of the economic activity. We first assess the contribution of publicly-listed firms to the U.S. economy and discuss the available datasets used for studying the financial behavior of private firms. We then provide details on the construction of the LOCUS dataset.

\subsection{Public Firms and Aggregate Economic Activity}

Between 2000 and 2013, around 6,600 firms were actively publicly traded annually, accounting for 0.13 percent of all firms in the economy. ${ }^{10}$ Less clear is the fraction of employment and revenue that these firms account for. Total U.S. employment is obtained from the Census Bureau's Business Dynamic Statistics (BDS). The BDS is derived from the LBD and covers 98 percent of non-government employment. Data are available annually and can be broken down by firm size, age, location, and sector. The total employment reported in the economy wide table is used to calculate the contribution of listed firms to total U.S. employment. The sector table includes 9 broad sectors, including finance, insurance, and real estate (FIRE). This table is used to calculate the contribution of non-FIRE listed firms to total non-FIRE U.S. employment. This second statistic is reported because our analysis focuses on the non-financial sector. ${ }^{11}$

Total U.S. gross output is obtained from the Bureau of Economic Analysis' Industry Economic Accounts. Gross output measures sales, including those to both final users and other

\footnotetext{
${ }^{10}$ The 6,600 figure is arrived at by beginning with Compustat and 1) keeping one observation per (gvkey, year) pair; 2) keeping (gvkey, year) pairs with a positive security price in the indicated year or in the years that bracket the indicated year, as in Davis, Haltiwanger, Jarmin and Miranda (2006);3) dropping financial instruments (ETFs, ADRs, etc), which involves dropping observations with missing NAICS codes and those with NAICS equal to $525 ; 4)$ dropping non-U.S. firms, which involves dropping observations with simultaneously missing EIN and state information or those with simultaneously missing EIN and a non-U.S. address; and 5) dropping firms in public administration (NAICS code 92 ). The 0.13 percent figure is arrived at by dividing 6,600 by $5,020,309$, which is the average number of firms in the U.S. economy between 2000 and 2013 derived from the Census Bureau's Business Dynamic Statistics data.

${ }^{11}$ This paper excludes only the finance and insurance sectors (NAICS code 52). The BDS groups finance and insurance (NAICS 52) with real estate, rental and leasing (NAICS 53). As a result, when calculating the contribution of listed firms to employment and revenue in non-financial sectors, we exclude FIRE (NAICS codes 52 and 53) from data used in the numerator (Compustat) and denominator (BDS and BEA).
} 
industries, and is measured in current prices. ${ }^{12}$ Total gross output by private industries is used in calculating the contribution of listed firms to total U.S. gross output. Total gross output by private industries net of the FIRE sector is used in calculate the contribution of non-FIRE listed firms to total non-FIRE U.S. gross output.

Calculating the contribution of listed firms to U.S. employment and gross output is not straightforward. First, not all firms in Compustat are actively traded. Following Davis et al. (2006), we define active listed firms as those with a positive security price in a particular year or in the years that bracket that year. More importantly, as noted in Davis et al. (2006), while the LBD measures the total number of employees that are subject to U.S. payroll taxes and total domestic revenue, Compustat measures the total number of employees and revenue of domestic and foreign subsidiaries. These differences give rise to discrepancies between the LBD and Compustat reported employment and revenue. Similar to Davis et al. (2006), we compare the LBD and Compustat employment and revenue of matched firms. Between 2007 and 2013, LBD employment is 75 percent of Compustat employment and LBD revenue is 79 percent of Compustat revenue. It is important to adjust Compustat reported employment and revenue when calculating the contribution of listed firms to the U.S. economy because the BDS measures domestic employment and the BEA measures domestic gross output.

To highlight the importance of taking into consideration these two factors, this paper reports several alternative measures of listed firms' contribution to the U.S. economy:

1. The first version ("raw") sums Compustat reported employment (emp) and revenue (revt) across all listed firms and divides it by total BDS employment and BEA gross output, respectively. ${ }^{13}$

2. The second version ("active") sums Compustat reported employment and revenue across all actively traded listed firms and divides it by total BDS employment and BEA gross output, respectively.

\footnotetext{
${ }^{12}$ Given the BEA definition of gross output, this measure corresponds to the revenue variable observed in Compustat. While the BEA provides data on gross output, other sources such as the BLS do not include this variable.

${ }^{13}$ The listed firms that are included are obtained by starting with Compustat and 1) keeping one observation per (gvkey, year); 2) dropping financial instruments (ETFs, ADRs, etc) which involves dropping observations with missing NAICS codes and those with NAICS equal to 525 ; 3) dropping non-U.S. firms, which involves dropping observations with simultaneously missing EIN and state information and those with simultaneously missing EIN and a non-U.S. address; and 5) dropping firms in public administration (NAICS code 92).
} 
3. The third version ("active \& adjusted") sums Compustat adjusted (by a factor 0.75) employment and adjusted (by a factor 0.79) revenue across all actively traded listed firms and divides it by total BDS employment and BEA gross output, respectively.

Figure 1 reports the contribution of listed firms to employment. The left panel depicts the contribution of listed firms to total employment and the right panel depicts the contribution of non-FIRE listed firms to non-FIRE employment. First, note that in both the left and right panels the contribution has remained quite stable over the entire period 2000-2013. In the left panel, Compustat firms appear to account for around 37\% of employment on average when no adjustments are made for active trading and foreign employment. This average falls to $34 \%$ if only actively-traded firms are considered and falls further still to $26 \%$ when the domestic employment of actively traded firms is considered. The right panel focuses on the non-FIRE private sector and here non-FIRE, actively traded listed firms account for around $25 \%$ of annual non-FIRE private sector employment after adjustment.

Figure 1: Employment: \% of Private Sector (left) and non-FIRE (right)
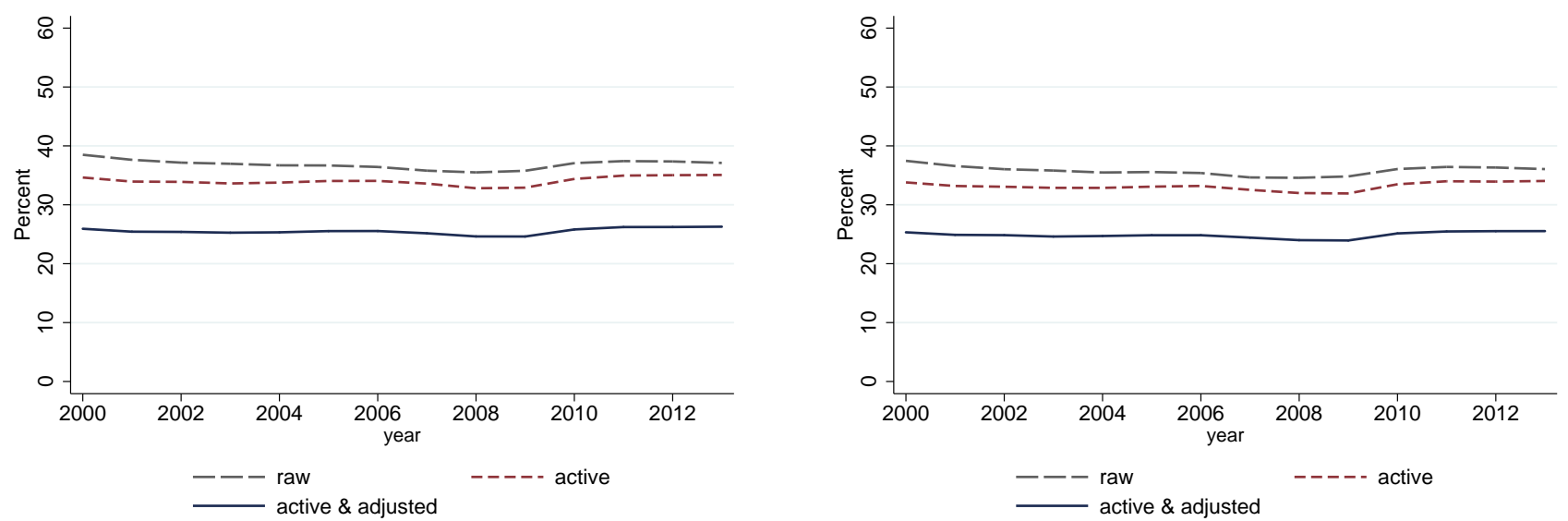

Notes: The left figure plots the contribution of listed firms to private sector employment. The right figure plots the contribution of non-FIRE listed firms to non-FIRE private sector employment. Listed firm employment is obtained from Compustat (revt variable) and private sector employment is obtained from the Census Bureau's BDS tables. In each figure the dashed grey line depicts the raw Compustat employment for listed firms over BDS employment; the dashed red line depicts the raw Compustat employment for actively traded listed firms over BDS employment; and the solid blue line depicts the adjusted (by a factor of 0.75) Compustat employment for actively traded listed firms over gross BDS employment.

Figure 2 reports the contribution of listed firms to gross output. The left panel depicts the contribution of listed firms to total gross output and the right panel depicts the contribution 
of non-FIRE listed firms to non-FIRE gross output. Similar to the employment contribution, in both the left and right panels the contribution of listed firms is fairly stable over time. In the left panel, Compustat firms appear to account for around $63 \%$ of private sector gross output on average when no adjustments are made for active trading and foreign employment. This average falls to $56 \%$ if only actively-traded firms are considered and falls further still to $44 \%$ when the domestic gross output of actively traded firms is considered. The right panel focuses on the non-FIRE private sector and here non-FIRE, actively traded listed firms account for around $46 \%$ of annual non-FIRE private sector gross output. Both figures confirm that publicly-traded firms account for an important share of the U.S. economy, but that privately-held firms account for the majority of employment (74\%) and gross output (56\%).

Figure 2: Gross Output: \% of Private Sector (left) and non-FIRE (right)
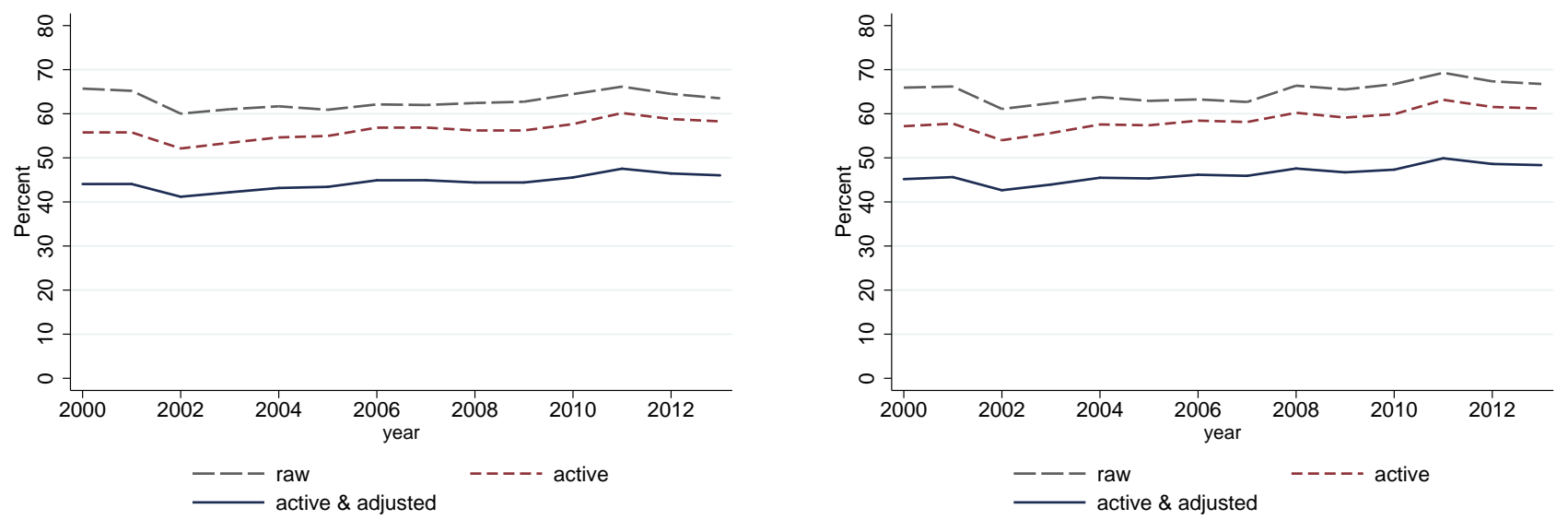

Notes: The left figure plots the contribution of listed firms to private sector gross output. The right figure plots the contribution of non-FIRE listed firms to non-FIRE private sector gross output. Listed firm gross output is obtained from Compustat (revt variable) and private sector gross output is obtained from the BEA's Industry Economic Accounts tables. In each figure the dashed grey line depicts the raw Compustat gross output for listed firms over BEA gross output; the dashed red line depicts the raw Compustat gross output for actively traded listed firms over BEA gross output; and the solid blue line depicts the adjusted (by a factor of 0.79) Compustat gross output for actively traded listed firms over gross BEA output.

\subsection{Existing Datasets for Private Firms}

Until recently, research on the financing behavior of private firms has relied mainly on two types of data. The first type, including SDC VentureXpert and CapitalIQ, focus on private equity issuances and buyouts. As a result, they provide no information on bank debt, and 
only include the very small sample of firms that raise private equity. ${ }^{14}$ The second type of data focuses on very small and very young businesses. The Survey of Small Business Finance (SSBF) is a cross-sectional survey conducted in four waves between 1987 and 2003 by the U.S. Federal Reserve. The 2003 survey, for instance, sampled under 5,000 firms from a target population of non-financial firms with less than 500 employees. ${ }^{15}$ Similarly, the Kauffman Firm Survey (KFS) focuses on the experience of young firms. It tracks a single cohort of 5,000 firms born in 2004 through $2011 .{ }^{16}$ These data cover a very select set of private firms that are not representative of the US economy, and the firm age and size distributions.

More recently, two exceptions that cover a larger set of private firms have been studied - the U.S. Census Bureau's Quarterly Financial Report (QFR) survey and Sageworks. QFR covers the mining, manufacturing, wholesale, retail and select service sectors. Each quarter, it surveys about 4,600 large corporations in these sectors, along with a select sample of about 5,000 small and medium sized firms in the manufacturing sector. It contains detailed balance sheet information for several thousand private and listed firms across the age and size distributions in the manufacturing sector. Two features distinguish LOCUS from the QFR. First, LOCUS encompasses a large sample of small and large firms outside the manufacturing sector. Even for manufacturing, the distribution of firm revenue in LOCUS more closely resembles the full firm distribution in the LBD than does QFR. ${ }^{17}$ Second, QFR can only be linked to the LBD in Census years and consequently does not contain employment and age information.

Another proprietary database, Sageworks, contains panel data on over 220,000 listed and private firms. Similar to LOCUS, Sageworks includes information on firm balance sheets and income statements, as well as industry classification and geographic location. In contrast to LOCUS, Sageworks anonymizes firms (Asker, Farre-Mensa and Ljungqvist, 2015). This feature

\footnotetext{
${ }^{14}$ Bernstein, Giroud and Townsend (2016) uses VentureXpert to analyze how monitoring by venture capitalists affects the innovation and growth of 23,000 venture-backed companies between 1977 and 2006. Davis, Haltiwanger, Handley, Jarmin, Lerner and Miranda (2014) use CapitalIQ to track changes in jobs and productivity among a sample of 3,200 firms targeted for leveraged buyouts between 1980 and 2005.

${ }^{15}$ The SSBF has been used to study borrower-lender relationships as in Petersen and Rajan (2002) and the capital structure decisions of single-owner corporations as in Ang, Cole and Lawson (2010) and Cole (2013). Using the 1993 survey, Berger and Udell (1998) show that due to a high degree of informational opacity, small businesses depend more on funding provided by insiders and receive external funding primarily from private equity and debt markets, as opposed to the public market. By linking loan-level data from the Small Business Administration with the LBD, which covers only very small firms, Brown and Earle (2017) shows that when local credit conditions are weak, access to SBA loans is associated with job growth.

${ }^{16} \mathrm{Robb}$ and Robinson (2012) use the survey to document the importance of external financing, such as bank financing, for startups.

${ }^{17}$ Appendix A shows how the QFR coverage compares to the manufacturing sector in the LBD, Compustat and our LOCUS data using both revenue and total assets.
} 
prevents matching it to other sources, such as the LBD, that contain information on age and size (employment). Additionally, due to the inability to match the Sageworks data to census, a full assessment of how representative firms in the sample are relative of the whole U.S. economy cannot be performed.

\subsection{LOCUS Data: Matching LBD, Orbis, and Compustat}

The U.S. Census Bureau's LBD has comprehensive data on firm age, employment, and revenue for the entire universe of private firms, but lacks information on firm balance sheets. ${ }^{18}$ To study the financing behavior of private firms in the U.S., we construct LOCUS by matching LBD data to Orbis and Compustat using both national firm-level identifiers and an iterative probabilistic name and address matching procedure. ${ }^{19}$ From the LBD we obtain information on firm employment, revenue, age, industry, and legal form. Our financial data on listed firms come from Compustat, and our financial data on private firms come from Orbis. Both sources contain detailed firm-level balance sheets, income statements, and profit and loss accounts. Orbis is compiled by Moody's Bureau van Dijk Electronic Publishing (BvD). Firm-level administrative data is first collected by local Chambers of Commerce and the business registers. The data are then relayed to BvD through 40 different information providers. Although private company reporting is voluntary in the U.S., we show that LOCUS covers more firms than other datasets provided by alternative private vendors. ${ }^{20}$

In all, our matched LOCUS data contains over 180,000 unique firms, 97 percent of which are privately held. Our matched sample covers around 31 percent of U.S. employment, 35 percent of payroll, and 38 percent of U.S. non-farm, non-financial revenue. Privately held firms in our sample consistently account for about 10 percent of the U.S. economy. What is perhaps most striking is how vastly different listed and private firms are. On average, listed firms in our sample have 34 times larger employment (6,200 employees versus 170 employees) and 64 times higher revenue ( $\$ 293$ million versus $\$ 7.7$ million) than privately held firms.

Using employment from LBD and revenue from the revenue-enhanced LBD, figures 3 and

\footnotetext{
${ }^{18}$ While listed firms are legally required to disclose their financial statements, private firms are not. As a result, Compustat, which covers the universe of listed firms in the U.S., has been extensively relied upon in the literature to study firm financial structure and aggregate implications of financial frictions.

${ }^{19}$ See Appendix $\mathrm{B}$ for additional details on the matching procedure.

${ }^{20}$ To the best of our knowledge, the only other paper that uses ORBIS data for the U.S. is by Nikolov, Schmid and Steri (2017). However these authors do not match the ORBIS data to Census data. They show that private firms in ORBIS have higher leverage relative to the listed firms in Compustat, and are more profitable.
} 
4 show that LOCUS data vastly improve the coverage of small and medium sized firms both in terms of employment and revenue relative to the sample of listed (Compustat) firms on which the finance and macro-finance literatures are built.

Figure 3: Comparison of Employment Distributions: Private \& Public Firms

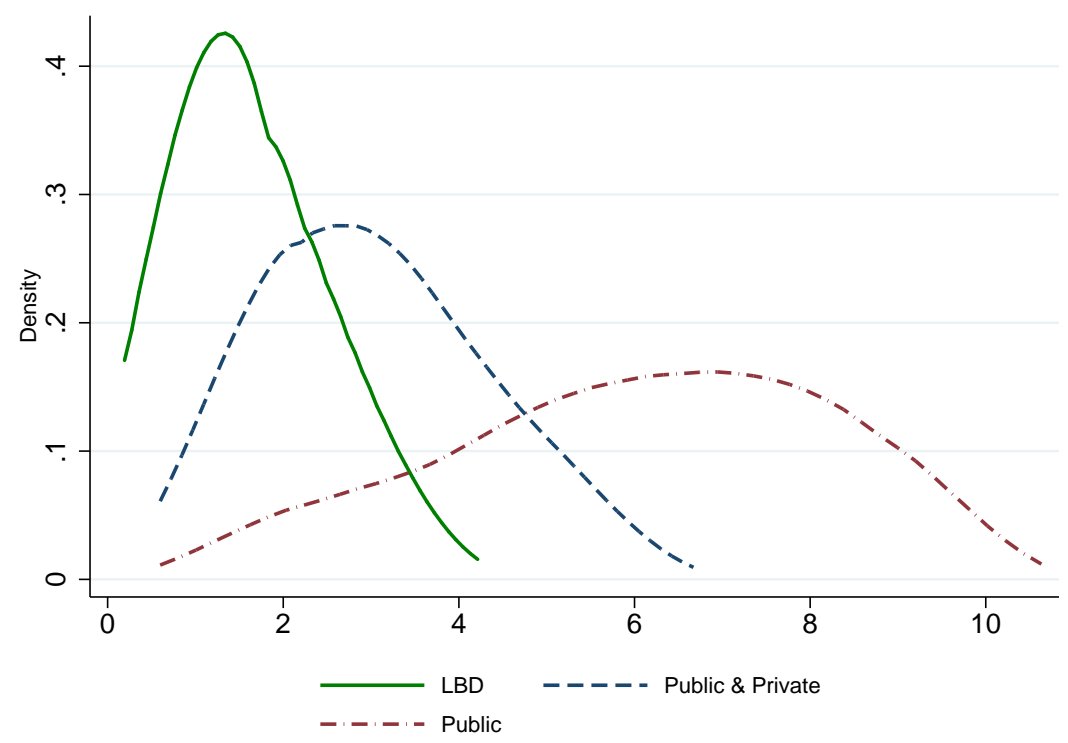

Notes: This figure compares the distribution of firm-level employment, obtained from the LBD, among nonfinancial employer businesses in 2010 that are in LOCUS (contains both private and listed firms), Compustat (listed firms only), and LBD. The distributions are generated using kernel density estimation and the top and bottom tails have been removed to comply with disclosure requirements 
Figure 4: Comparison of Revenue Distributions: Private \& Public Firms

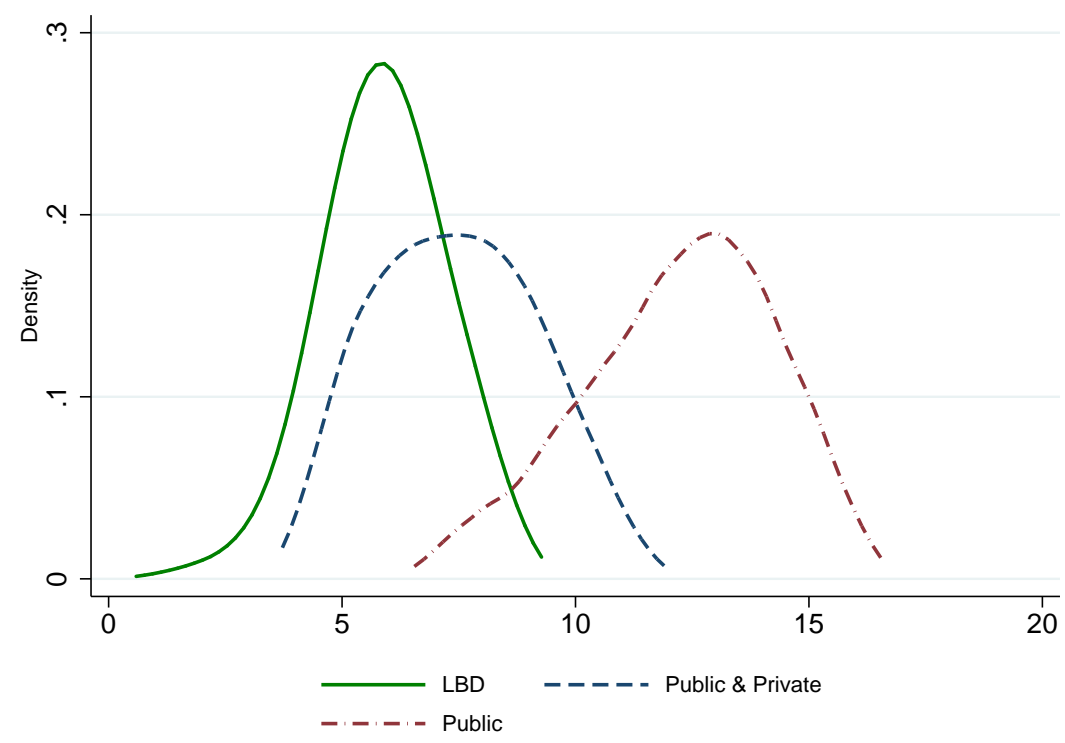

Notes: This figure compares the distribution of firm-level revenue, obtained from the revenue-enhanced LBD, among non-financial employer businesses in 2010 that are in LOCUS (contains both private and listed firms), Compustat (listed firms only), and LBD. The distributions are generated using kernel density estimation and the top and bottom tails have been removed to comply with disclosure requirements

Importantly, having private firms in the sample is also important for capturing the distribution of firm leverage. In figures 5 and 6 we focus on firms that have positive long-term leverage (figure 5) and positive short-term leverage (figure 6), which are respectively measured as longterm debt over total assets and short-term debt over total assets. We plot the distribution of these leverage measures separately for private firms (solid blue line) and publicly-listed firms (dashed red line).

Conditional on having positive debt, public firms appear to have higher long-term leverage and lower short-term leverage than private firms. The higher long-term leverage among public firms in figure 5 may be a result of easier access to various forms of financing. Note that the higher short-term leverage among private firms in figure 6 may make these firms relatively more vulnerable to financial shocks. In crisis, they may be forced to deleverage. The stark difference in leverage distributions for public and private firms in short-term leverage (the relevant measure in most macro-finance models) highlights the importance of studying private firms' financing patterns and their implications for aggregate fluctuations. 
Figure 5: Long-term Leverage Distributions: Private \& Public Firms

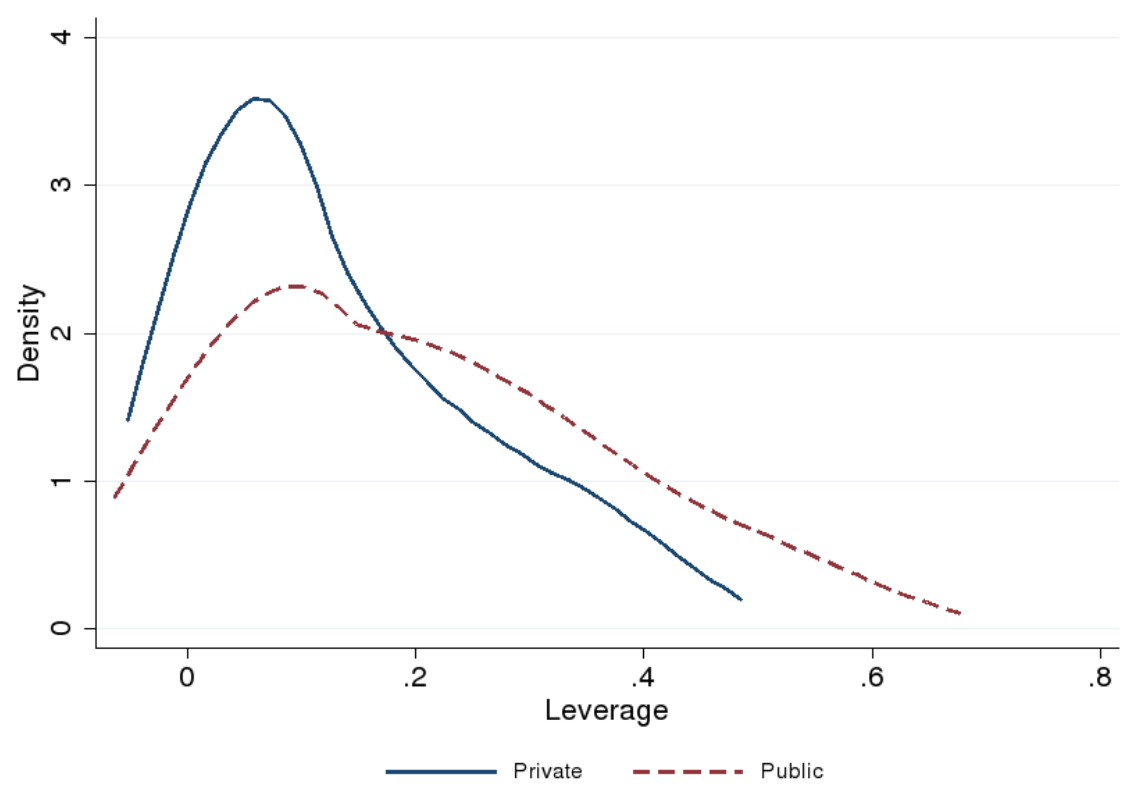

Notes: This figure compares the distribution of firm-level long-term leverage (long-term debt divided by total assets) for private firms (solid blue line) in LOCUS and publicly-listed firms (dashed red line). The distributions are conditional on positive leverage and are generated using kernel density estimation. The top and bottom tails have been removed to comply with disclosure requirements

\section{Figure 6: Short-term Leverage Distributions: Private \& Public Firms}

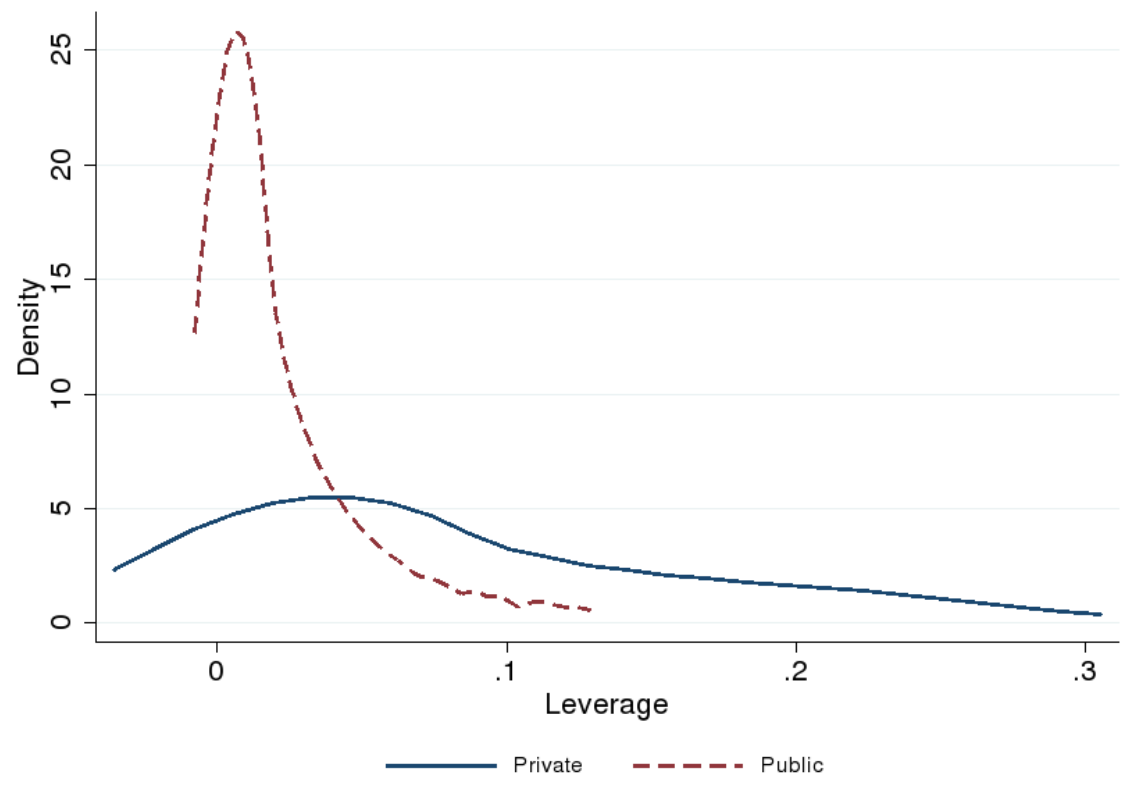

Notes: This figure compares the distribution of firm-level short-term leverage (short-term debt divided by total assets) for private firms (solid blue line) in LOCUS and publicly-listed firms (dashed red line). The distributions are conditional on positive leverage and are generated using kernel density estimation. The top and bottom tails have been removed to comply with disclosure requirements 


\subsection{LOCUS Data: Accounting for Selection}

Although figures 3 and 4 show that LOCUS resembles the LBD size distribution more closely than Compustat, they also illustrate that LOCUS is not representative of the U.S. economy. In both figures, LOCUS data are to the right of the LBD. The average employment in LOCUS is 525 versus just 20 in the LBD; and the average age is 21 in LOCUS versus 11 in the LBD. Additionally, LOCUS firms tend to have higher employment growth rates, are more likely to own multiple establishments, and are more likely to be nonprofits than firms in the LBD. This selection is driven by the fact that our sample contains only privately-held firms that report their financials. The non-representativeness of LOCUS is a concern because we believe that firm financing decisions are influenced by factors such as age, size, growth, and legal form. Analysis based on the raw, unweighted LOCUS data will therefore likely misrepresent the relationship between leverage and firm characteristics because the average firm in our raw data is older, larger, and grows faster than the average firm in the U.S. economy.

We are able to address selection head-on because we matched Orbis to the LBD. We implement a series of logistic regressions similar to Haltiwanger, Jarmin, Kulick and Miranda (2017) for private firms. ${ }^{21}$ Our dependent variable is annual reporting status for financial information, and is equal to one for the firm-year observations in LOCUS. To account for the possibility that selection into our matched data varies over time, we estimate separate models for each year, 2005 through 2012. To further account for the possibility that selection varies for firms continuing, entering and exiting the universe of employer-businesses, we estimate separate models for each of these categories. Our explanatory variables are firm employment $\left(\log \left(e m p_{i}\right)\right)$, age $\left(a g e_{i}\right)$, an indicator for firms 16 years or older $\left(D 16_{i}\right)$, employment growth rate ( $E G_{i}, 7$ categories), and a series of fixed effects for 3-digit NAICS industry (ind), multi-unit status $(m u)$, and legal form ( $l f o, 3$ categories). ${ }^{22}$ The models are depicted below:

\section{Continuers:}

$$
R_{i t}=\alpha+\gamma_{1} \log \left(e m p_{i t}\right)+\gamma_{2} a g e_{i t}+\gamma_{3} D 16_{i}+\gamma_{4} E G_{i t}+i n d_{i}+m u_{i t}+l f o_{i t}+\varepsilon_{i t}
$$

\footnotetext{
${ }^{21}$ We exclude listed firms from the logistic regressions and assign them a weight of one in our subsequent analysis because they are required to report financials. As a result, LOCUS includes all identifiable listed firms in the LBD.

${ }^{22}$ Legal form is divided into three categories - 1) corporation, 2) sole-proprietorship, partnership, and Scorporation, and 3) non-profits and other legal forms.
} 


\section{Entrants:}

$$
R_{i t}=\alpha+\beta_{1} \ln \left(e m p_{i t}\right)+i n d_{i}+m u_{i t}+l f o_{i t}+\varepsilon_{i t}
$$

\section{Exiters:}

$$
R_{i t}=\alpha+\delta_{1} \log \left(e m p_{i t}\right)+\delta_{2} a g e_{i t}+\delta_{3} D 16_{i t}+i n d_{i}+m u_{i t}+l f o_{i t}+\varepsilon_{i t}
$$

The resulting predicted values are used to construct propensity scores, which serve as weights in the remainder of the analysis. As figures 7 through 9 and tables 1 and 2 show, applying weights substantially decreases the observable differences between financial reporting and non-reporting privately-held firms. ${ }^{23}$ In particular, the weights reduce the over-representation of old, large and multi-unit firms in the unweighted LOCUS data. The approach also addresses the over-representation of non-profit firms, which likely make different financing decisions than sole-proprietorships, partnerships and corporations.

In table 3, we compare the weighted means and standard deviations of key variables for the public and private firms in LOCUS. In constructing our analysis data, we winsorize all financial variables - collateral, profitability, equity over total assets and all leverage variables - at the 1st and 99th percentiles. Listed firms are 62 times larger than private ones and twice as old. Listed firms also are more profitable, and have higher collateral, total leverage and financial leverage. When we decompose leverage into short-term and long-term, private firms have higher short-term leverage, while public firms have higher long-term leverage. Private firms also have higher equity-to-assets ratio, which could reflect their higher reliance on internal equity relative to the listed firms.

\footnotetext{
${ }^{23}$ In the figures the height of each bar and in the tables the share reported is the share of each sample employment accounted for by each group.
} 


\section{Figure 7: Comparison of Firm Age Distributions (\% of emp)}

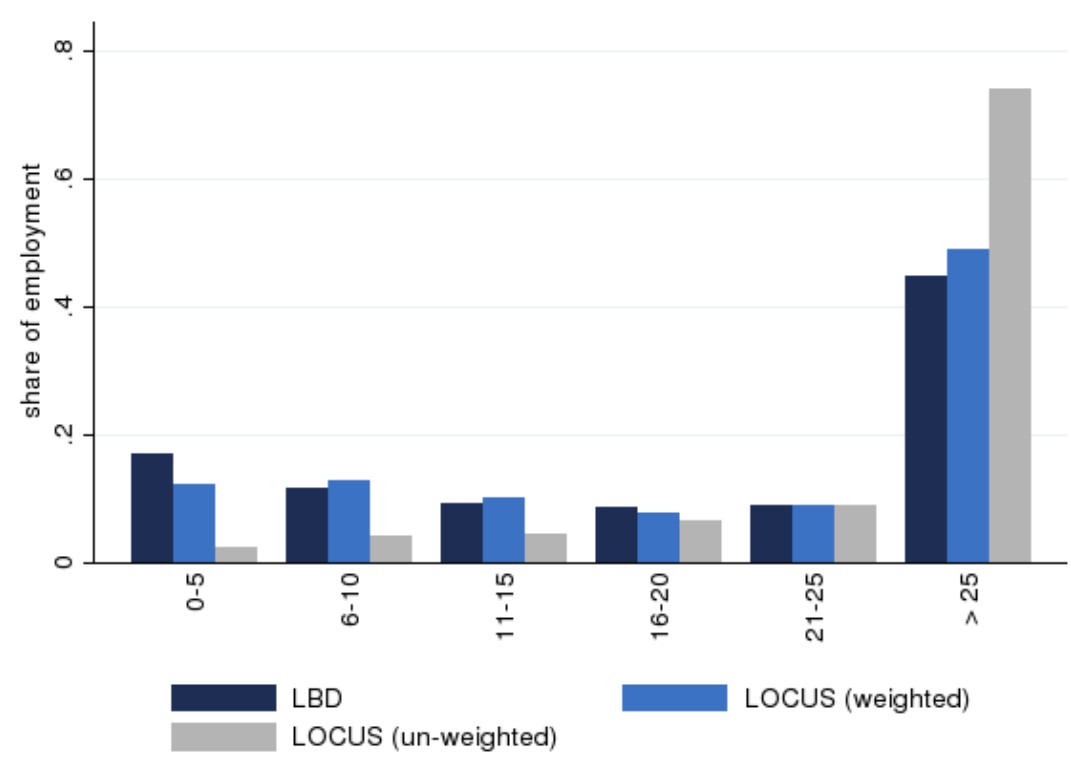

Notes: This figure compares the fraction of sample firm-level employment accounted for by each age group. Each bar represents a different sample. The first bar represents all private, non-financial employer businesses in the LBD. The second bar represents the weighted LOCUS sample of private firms, where the weights are derived from estimating equations (3) through (5). The third bar represents the unweighted LOCUS sample of private firms, where each firm gets equal weight.

\section{Figure 8: Comparison of Firm Employment Distributions (\% of emp)}

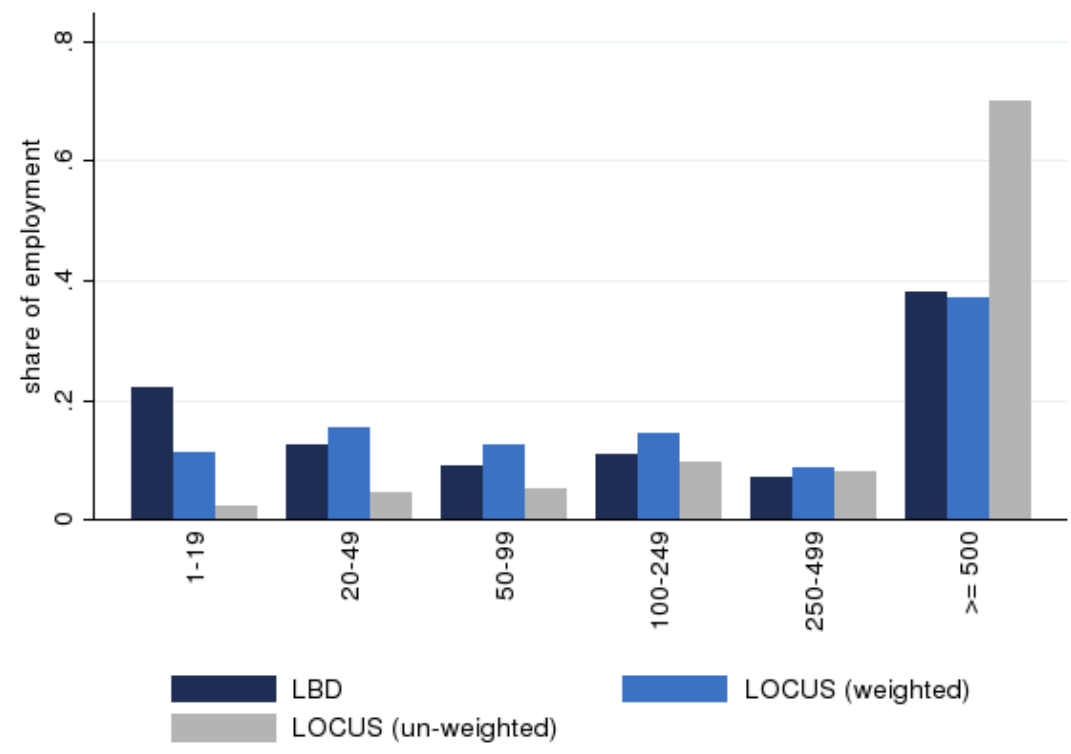

Notes: This figure compares the fraction of sample firm-level employment accounted for by each size group. Each bar represents a different sample. The first bar represents all private, non-financial employer businesses in the LBD. The second bar represents the weighted LOCUS sample of private firms, where the weights are derived from estimating equations (3) through (5). The third bar represents the unweighted LOCUS sample of private firms, where each firm gets equal weight. 
Figure 9: Comparison Firm Employment Growth Distributions (\% of emp)

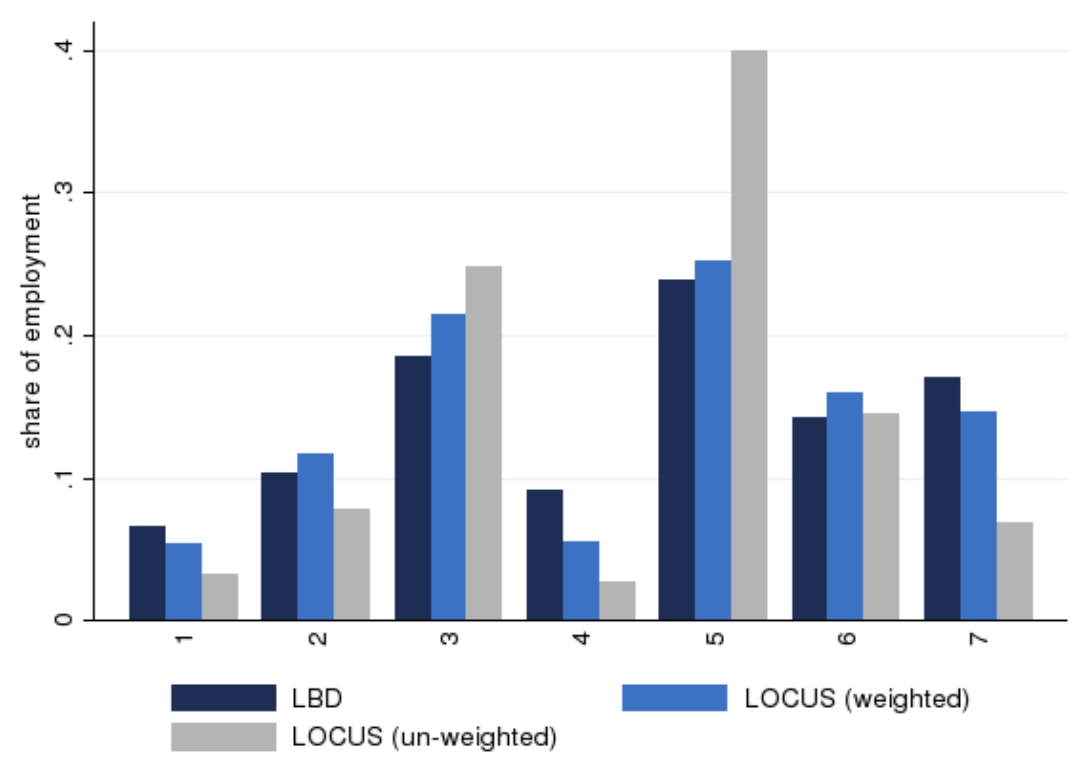

Notes: This figure compares the fraction of sample firm-level employment accounted for by each employment growth group. Each bar represents a different sample. The first bar represents all private, non-financial employer businesses in the LBD. The second bar represents the weighted LOCUS sample of private firms, where the weights are derived from estimating equations (3) through (5). The third bar represents the unweighted LOCUS sample of private firms, where each firm gets equal weight.

Table 1: Comparison of Multi-unit Status Distributions (\% of emp)

\begin{tabular}{lccc}
\hline \hline & LOCUS (unweighted) & LOCUS (weighted) & LBD \\
\hline Single-unit & $20.73 \%$ & $46.09 \%$ & $53.93 \%$ \\
Multi-unit & $79.27 \%$ & $53.91 \%$ & $46.07 \%$ \\
\hline \hline
\end{tabular}

Notes: This table compares the fraction of sample firm-level employment accounted for by single- and multi-unit firms. Each column represents a different sample. The first column represents all private, non-financial employer businesses in the LBD. The second column represents the weighted LOCUS sample of private firms, where the weights are derived from estimating equations (3) through (5). The third column represents the unweighted LOCUS sample of private firms, where each firm gets equal weight. 
Table 2: Comparison of Legal Form Distributions (\% of emp)

\begin{tabular}{lccc}
\hline \hline & LOCUS (unweighted) & LOCUS (weighted) & LBD \\
\hline Corp. & $42.29 \%$ & $46.22 \%$ & 47.31 \\
S-Corp., Sole-prop. \& Partner. & $12.41 \%$ & $43.71 \%$ & 36.47 \\
Other & $45.3 \%$ & $10.08 \%$ & 16.22 \\
\hline \hline
\end{tabular}

Notes: This table compares the fraction of sample firm-level employment accounted for by each legal form group. Each column represents a different sample. The first column represents all private, non-financial employer businesses in the LBD. The second column represents the weighted LOCUS sample of private firms, where the weights are derived from estimating equations (3) through (5). The third column represents the unweighted LOCUS sample of private firms, where each firm gets equal weight.

Table 3: Summary Statistics table: LOCUS (weighted) Data

\begin{tabular}{lcc|cc}
\hline \hline & \multicolumn{2}{c|}{ Private } & \multicolumn{2}{c}{ Public } \\
\hline & mean & stdev & mean & stdev \\
\hline Employment & 100 & & 6,200 & \\
Age & 11 & & 24 & \\
Log(Employment) & 1.8 & 1.6 & 6.3 & 2.4 \\
Log(Age) & 1.9 & 1.2 & 3.0 & 0.7 \\
Collateral & 0.17 & 0.24 & 0.24 & 0.23 \\
Profitability & 0.13 & 0.40 & 0.22 & 0.34 \\
Total Leverage & 0.46 & 0.38 & 0.56 & 0.36 \\
Financial Leverage & 0.16 & 0.24 & 0.21 & 0.24 \\
Short-term Leverage & 0.04 & 0.11 & 0.03 & 0.08 \\
Long-term Leverage & 0.12 & 0.22 & 0.18 & 0.21 \\
Equity/Total Assets & 0.48 & 0.38 & 0.44 & 0.36 \\
\hline \hline
\end{tabular}

Notes: This table compares the mean and standard deviation of key variables for private and public firms. The means and standard deviations are weighted, where the weights are derived from estimating equations (3) through (5). Employment measures firm-level total employment. Age measures the firm age. Collateral is measured as tangible fixed assets over total assets. Profitability is net income over total assets. Total leverage is total liabilities over total assets. Financial leverage is short-term debt plus long-term debt over total assets. Short-term leverage is short-term debt over total assets. Long-term leverage is long-term loans over total assets. Equity/total assets is total shareholder funds over total assets. 


\section{Firm Financing and Life-Cycle Dynamics in LOCUS}

Having accounted for selection using weights, we first turn to studying how firms finance their operations. We do so by first documenting patterns of leverage as a function of firms' life-cycle characteristics in the cross-section and within firms over time, and then exploring potential non-linearities in these patterns.

\subsection{Cross-Sectional and Within Firm Relationships}

To emphasize how private and listed firms differ, we run the following standard leverage regressions separately for each type of firm:

$$
\begin{aligned}
L E V_{i t}= & \alpha+\left(\omega_{s} \times \lambda_{t}\right)+\beta_{1} \log \left(E M P_{i t}\right)+\beta_{2} A G E_{i t}+\beta_{3} C O L L A T_{i t}+ \\
& \beta_{4} \text { PROFIT }_{i t}+\beta_{5} \text { PROD }_{i t}+\epsilon_{i t}
\end{aligned}
$$

where $i$ is the firm and $t$ is time, measured in years. $\left(\omega_{s} \times \lambda_{t}\right)$ are sector $\times$ year fixed effects, where sector is at the 3-digit level. These fixed effects will account for any time varying sectoral selection effects. Notice that this regression identifies from between firm variation since we do not include firm fixed effects. Inclusion of these fixed effects will render the firm age variable irrelevant since its effect will be absorbed by firm fixed effects and time dummies. Since we are interested in the effect of firm age we run this regression first. We then drop firm age and introduce firm fixed effects, and run a panel version of this regression that identifies from within variation.

The above regression is a standard firm leverage regression with firm collateral (COLLAT $T_{i t}$ ) and profitability $\left(P R O F I T_{i t}\right)$, where we add employment $\left(\log \left(E M P_{i t}\right)\right)$ and age $\left(A G E_{i t}\right)$ as regressors to capture life-cycle stages of firms. The corporate finance literature also controls for size, mainly by using assets. Given the valuation effects, employment is a more appropriate measure of size since book value of assets will not reflect true size and market value of assets may not reflect true firm growth. The literature also uses cash flow and Tobin's $Q$ as measures of productivity and growth potential. Adding cash flow does not change any of our results. Since 97 percent of our sample is composed of private firms we do not use a Tobin's $Q$ measure. Instead, we use labor productivity $\left(P R O D_{i t}\right)$ to control for growth potential. 
We focus on three standard measures of leverage as the dependent variables: financial debt, short-term debt and long-term debt, each divided by total assets. Both collateral and profitability are also normalized by assets. In particular, we construct tangible fixed assets-tototal assets ratio for collateral and net income-to-total assets ratio for profitability. ${ }^{24}$

We run regressions separately for listed and private firms. As shown in table 4, among both listed and private firms collateral is positively related to leverage, and profitability is negatively related. These results mimic the results in the previous literature. The only exception is the negative sign on collateral for the private firms' short-term borrowing. This is likely due to a compositional effect. Total leverage for private firms, measured as financial debt over total assets, is positively related to collateral. The negative coefficient for short-term borrowing may be a result of private firms with a lot of collateral switching from short to long-term debt.

The new results here are on firm size and age. As previously mentioned, models of financial frictions generally focus only on short-term debt, so we distinguish between total, short-term and long-term leverage in discussing our results. We find that firm size (employment) is positively correlated with firm leverage for private firms for all forms of debt. A one standard deviation increase in size is associated with a $24 \%$ rise in overall leverage, a $37 \%$ rise in short-term leverage, and a 19\% rise in long-term leverage. In contrast, for public firms size is negatively correlated with short-term leverage. A one standard deviation increase in size is associated with a $13 \%$ decline in short-term leverage among public firms.

If we focused only on the listed firms, we would conclude that our results contradict many firm dynamics models with firm heterogeneity and financial frictions, which predict that smaller firms have lower short-term leverage. But private firms, which account for over 55 percent of the economy, tell a different story. The positive correlation between leverage and size supports models featuring decreasing returns to scale and models with explicit heterogeneity in borrowing constraints as a function of size. Our findings suggest that size is a measure of financial constraints for private firms but not for listed ones, since small private firms cannot borrow short-term while small listed firms can.

Turning to firm age, we find that it has no significant connection with public firms' short-

\footnotetext{
${ }^{24}$ Profits-to-total assets is the standard measure of profitability, but the ORBIS data contains many missing records for profits. Net income over total assets is used instead and for the subsample for which both profits and net income is available, we verify that there is a high correlation between profits over total assets and net income over total assets.
} 
term leverage and is positively related to long-term leverage, inconsistent with the theoretical literature that predicts a negative relationship. For public firms, a one standard deviation increase in firm age is associated with roughly a 3\% rise in long-term leverage. Here again, the experience of private firms is crucial. Private firms borrow more and have higher leverage when they are young. The negative relationship is particularly strong for long-term leverage. A one standard deviation increase in age is associated with about a $12 \%$ decline in short-term leverage and a $20 \%$ decline in long-term leverage. These patterns are consistent with financial frictions models, which predict that firms pay down long-term debt as they age. These results show that age is not a good proxy for financial constraints, while size appears to be a more appropriate one. 
Table 4: Leverage Regressions for Private \& Listed Firms (2005-2012)

\begin{tabular}{|c|c|c|c|c|c|c|}
\hline & \multicolumn{2}{|c|}{$\left(\mathrm{FD} / \mathrm{TA}_{i t}\right)$} & \multicolumn{2}{|c|}{$\left(\mathrm{STL} / \mathrm{TA}_{i t}\right)$} & \multicolumn{2}{|c|}{$\left(\mathrm{LTL} / \mathrm{TA}_{i t}\right)$} \\
\hline & Listed & Private & Listed & Private & Listed & Private \\
\hline \multirow[t]{2}{*}{$\log \left(\mathrm{EMP}_{i t}\right)$} & $0.0178^{* * *}$ & $0.0281^{* * *}$ & $-0.0014^{* * *}$ & $0.0117^{* * *}$ & $0.0195^{* * *}$ & $0.0167^{* * *}$ \\
\hline & $(0.0008)$ & $(0.0007)$ & $(0.0003)$ & $(0.0003)$ & $(0.0007)$ & $(0.0006)$ \\
\hline \multirow[t]{2}{*}{$\mathrm{AGE}_{i t}$} & $0.0007^{* * *}$ & $-0.0024^{* * *}$ & 0.0001 & $-0.0004^{* * *}$ & $0.0006^{* * *}$ & $-0.0019^{* * *}$ \\
\hline & $(0.0002)$ & $(0.0001)$ & $(0.0001)$ & $(0.0000)$ & $(0.0002)$ & $(0.0001)$ \\
\hline \multirow[t]{2}{*}{$\operatorname{COLLAT}_{i t}$} & $0.2321^{* * *}$ & $0.1861^{* * *}$ & $0.0265^{* * *}$ & $-0.0296^{* * *}$ & $0.2023^{* * *}$ & $0.2118^{* * *}$ \\
\hline & $(0.0112)$ & $(0.0049)$ & $(0.0043)$ & $(0.0021)$ & $(0.0102)$ & $(0.0045)$ \\
\hline \multirow[t]{2}{*}{ PROFIT $_{i t}$} & $-0.1928^{* * *}$ & $-0.0702^{* * *}$ & $-0.0688^{* * *}$ & $-0.0290^{* * *}$ & $-0.1178^{* * *}$ & $-0.0402^{* * *}$ \\
\hline & $(0.0090)$ & $(0.0037)$ & $(0.0044)$ & $(0.0019)$ & $(0.0076)$ & $(0.0030)$ \\
\hline \multirow[t]{2}{*}{$\mathrm{PROD}_{i t}$} & $0.0061^{* * *}$ & $0.0087^{* * *}$ & 0.0009 & $0.0088^{* * *}$ & $0.0053^{* * *}$ & -0.0000 \\
\hline & $(0.0020)$ & $(0.0011)$ & $(0.0007)$ & $(0.0006)$ & $(0.0018)$ & $(0.0009)$ \\
\hline Constant & Yes & Yes & Yes & Yes & Yes & Yes \\
\hline Industry-Year FE & Yes & Yes & Yes & Yes & Yes & Yes \\
\hline Wgts (logit) & Yes & Yes & Yes & Yes & Yes & Yes \\
\hline Obs. & 20,000 & 320,000 & 20,000 & 320,000 & 20,000 & 320,000 \\
\hline $\mathrm{R} 2$ & 0.2299 & 0.1525 & 0.1164 & 0.0882 & 0.2275 & 0.1523 \\
\hline
\end{tabular}

Notes: We consider unbalanced samples of private and publicly-listed firms separately between the years 2005 and 2012. The dependent variables are financial debt/total assets $\left(\mathrm{FD} / \mathrm{TA}_{i t}\right)$ in the first two columns, short-term debt/total assets $\left(\mathrm{STL} / \mathrm{TA}_{i t}\right)$ in the next two columns, and long-term loans/total assets $\left(\mathrm{LTL} / \mathrm{TA}_{i t}\right)$ in the last two columns. The main regressors are $\log \left(\mathrm{EMP}_{i t}\right)$ to measure firm size; $\mathrm{AGE}_{i t}$ to measure firm age; $\mathrm{COLLAT}$ it to measure tangible fixed assets over total assets; PROFIT $_{i t}$ to measure net income over total assets; and PROD $i t$ to measure log labor productivity. All regressions include a full set of 3-digit industry-year fixed effects. All observations are weighted to adjust for selection into the LOCUS sample, as detailed in section 3. Standard errors are robust. ${ }^{* * *}, * *$, and ${ }^{*}$ indicates significance at the $1 \%, 5 \%$, and $10 \%$ levels,respectively.

We now verify whether our firm size results hold beyond the cross-sectional setting. To do so, we drop age as a regressor, lag all regressors by one period, and introduce firm fixed-effects:

$$
\begin{aligned}
L E V_{i t}= & \alpha_{i}+\left(\omega_{s} \times \lambda_{t}\right)+\beta_{1} \log \left(E M P_{i t-1}\right)+\beta_{2} \text { COLLAT }_{i t-1}+ \\
& \beta_{3} \text { PROFIT }_{i t-1}+\beta_{4} \text { PROD }_{i t-1}+\epsilon_{i t}
\end{aligned}
$$

We focus on a balanced sub-sample of firms for which we have data over the period 2005 
through 2011, and run regressions separately for private and listed firms. ${ }^{25}$ From the theoretical financial frictions literature, we would anticipate that leverage rises as firms grow due to loosening financial constraints. Since these models primarily focus on short-term lending, we are particularly interested in the relationship between short-term leverage and size. As table 5 shows, we do find that leverage and employment are positively related in a panel setting. This finding is noteworthy since in typical leverage regressions using public data the inclusion of fixed effects renders other variables insignificant. The results in table 5 are driven by private firms and mainly apply for the case of short-term leverage. This pattern is to be expected because private firms are subject to more financial frictions than listed firms. Moreover, they face more frictions in short-term borrowing, which is also the focus of financial frictions models.

Table 5: Balanced Panel (2005-2011)

\begin{tabular}{|c|c|c|c|c|c|c|}
\hline & \multicolumn{3}{|c|}{ (Listed) } & \multicolumn{3}{|c|}{ (Private) } \\
\hline & $\mathrm{FD} / \mathrm{TA}_{i t}$ & $\mathrm{STL} \mathrm{TA}_{i t}$ & $\mathrm{LTL} / \mathrm{TA}_{i t}$ & $\mathrm{FD} / \mathrm{TA}_{i t}$ & $\mathrm{STL} / \mathrm{TA}_{i t}$ & $\mathrm{LTL} / \mathrm{TA}_{i t}$ \\
\hline $\log \left(\mathrm{EMP}_{i t-1}\right)$ & $\begin{array}{c}0.0072 \\
(0.0057)\end{array}$ & $\begin{array}{c}0.0024 \\
(0.0024)\end{array}$ & $\begin{array}{c}0.0025 \\
(0.0051)\end{array}$ & $\begin{array}{c}0.0101 \\
(0.0069)\end{array}$ & $\begin{array}{c}0.0066^{* *} \\
(0.0033)\end{array}$ & $\begin{array}{c}0.0027 \\
(0.0061)\end{array}$ \\
\hline $\mathrm{COLLAT}_{i t-1}$ & $\begin{array}{c}0.1199^{* * *} \\
(0.0344)\end{array}$ & $\begin{array}{c}0.0097 \\
(0.0156)\end{array}$ & $\begin{array}{c}0.1134^{* * *} \\
(0.0333)\end{array}$ & $\begin{array}{c}0.0463^{* * *} \\
(0.0141)\end{array}$ & $\begin{array}{l}-0.0019 \\
(0.0101)\end{array}$ & $\begin{array}{c}0.0495^{* * *} \\
(0.0148)\end{array}$ \\
\hline PROFIT $_{i t-1}$ & $\begin{array}{c}-0.0516^{* * *} \\
(0.0098)\end{array}$ & $\begin{array}{c}-0.0230^{* * *} \\
(0.0056)\end{array}$ & $\begin{array}{c}-0.0333^{* * *} \\
(0.0105)\end{array}$ & $\begin{array}{c}0.0091 \\
(0.0102)\end{array}$ & $\begin{array}{l}-0.0001 \\
(0.0034)\end{array}$ & $\begin{array}{c}0.0123 \\
(0.0097)\end{array}$ \\
\hline $\mathrm{PROD}_{i t-1}$ & $\begin{array}{l}-0.0037 \\
(0.0049) \\
\end{array}$ & $\begin{array}{l}-0.0005 \\
(0.0014) \\
\end{array}$ & $\begin{array}{l}-0.0033 \\
(0.0047) \\
\end{array}$ & $\begin{array}{l}-0.0027 \\
(0.0054)\end{array}$ & $\begin{array}{c}0.0017 \\
(0.0026) \\
\end{array}$ & $\begin{array}{l}-0.0039 \\
(0.0048) \\
\end{array}$ \\
\hline Industry-Year FE & Yes & Yes & Yes & Yes & Yes & Yes \\
\hline Firm FE & Yes & Yes & Yes & Yes & Yes & Yes \\
\hline Wgts (logit) & Yes & Yes & Yes & Yes & Yes & Yes \\
\hline Obs. & 10,000 & 10,000 & 10,000 & 19,000 & 19,000 & 17,000 \\
\hline $\mathrm{R} 2$ & 0.8637 & 0.5542 & 0.8410 & 0.7720 & 0.6271 & 0.7904 \\
\hline
\end{tabular}

Notes: We consider balanced samples of private and publicly-listed firms separately between the years 2005 and 2011. The dependent variables are financial debt/total assets $\left(\mathrm{FD} / \mathrm{TA}_{i t}\right)$, short-term debt/total assets $\left(\mathrm{STL} / \mathrm{TA}_{i t}\right)$, and long-term loans/total assets $\left(\mathrm{LTL} / \mathrm{TA}_{i t}\right)$ in the last two columns. The main regressors are $\log \left(\mathrm{EMP}_{i t-1}\right)$ to measure firm size; COLLAT $i t-1$ to measure tangible fixed assets over total assets; PROFIT $_{i t-1}$ to measure net income over total assets; and $\mathrm{PROD}_{i t-1}$ to measure log labor productivity. All regressions include a full set of 3-digit industry-year fixed effects and firm fixed effects. All observations are weighted to adjust for selection into the LOCUS sample, as detailed in section 3 . Standard errors are robust. ${ }^{* * *},{ }^{* *}$, and ${ }^{*}$ indicates significance at the $1 \%, 5 \%$, and $10 \%$ levels,respectively.

\footnotetext{
${ }^{25}$ Orbis coverage of firms in 2012 is limited because it is the end of the data collection period, around which time there are reporting and data gathering lags. Therefore, the balanced sample is restricted to the period 20052011.
} 


\subsection{Nonlinear Relationships}

To explore possible non-linearities in the relationship between leverage, size, and age, we introduce introduce a quadratic term for $(\log )$ employment or age in the regressions specified in the previous section. Figures 10 through 12 and figures 13 through 15 plot the predicted values of the dependent variable as a function of the independent variable of interest (size or age), holding all other variables at their means. Since financial debt is primarily composed of long-term loans, financial leverage behaves similar to long-term leverage. As a result, we only report figures associated with financial and short-term leverage. We also consider total equity (both internal and external) over total assets to understand how firms substitute between debt and equity financing.

We consider the following regressions to explore non-linearity:

$$
\begin{gathered}
L E V_{i t}=\alpha+\left(\omega_{s} \times \lambda_{t}\right)+\beta_{1} \log \left(S_{I Z E_{i t}}\right)+\beta_{2} \log \left(S_{I Z E_{i t}}\right)^{2}+\beta_{3} A G E_{i t}+\beta_{4} C O L L A T_{i t}+ \\
\beta_{5} \text { PROFIT }_{i t}+\beta_{6} \operatorname{PROD}_{i t}+\epsilon_{i t} \\
L E V_{i t}=\alpha+\left(\omega_{s} \times \lambda_{t}\right)+\beta_{1} A G E_{i t}+\beta_{2} A G E_{i t}^{2}+\beta_{3} \log \left(S_{I Z E_{i t}}\right)+\beta_{4} C_{C O L L A T}+ \\
\beta_{5} \text { PROFIT }_{i t}+\beta_{6} \text { PROD }_{i t}+\epsilon_{i t}
\end{gathered}
$$

Focusing first on the figures with quadratic employment, size is more strongly positively associated with debt financing (both overall and short-term) among private firms than public ones (figure 10 and 11). In fact, the relationship between size and short-term leverage is rather flat for listed firms. This finding is consistent with private firms facing more financial frictions than listed ones. Note also that there is a log-convex relationship between long-term leverage and size for private firms, but the short-term leverage and size relationship is log-concave. This can be due to the fact that it is even harder to access long term finance for small private firms.

Among private firms there is a strong negative relationship between total equity over total assets and employment (figure 12). One interpretation is that as financial constraints ease, private firms choose debt financing over internal equity. The equity-size relationship has an inverted U-shape for public firms. Since these firms have access to external equity via stock issuances, one interpretation is that small and medium sized listed firms complement long- 
term debt with external equity. As they become larger, they appear to issue less external equity and turn more toward long-term debt borrowing.

\section{Figure 10: Quadratic Relationship between FD/TA and Size}

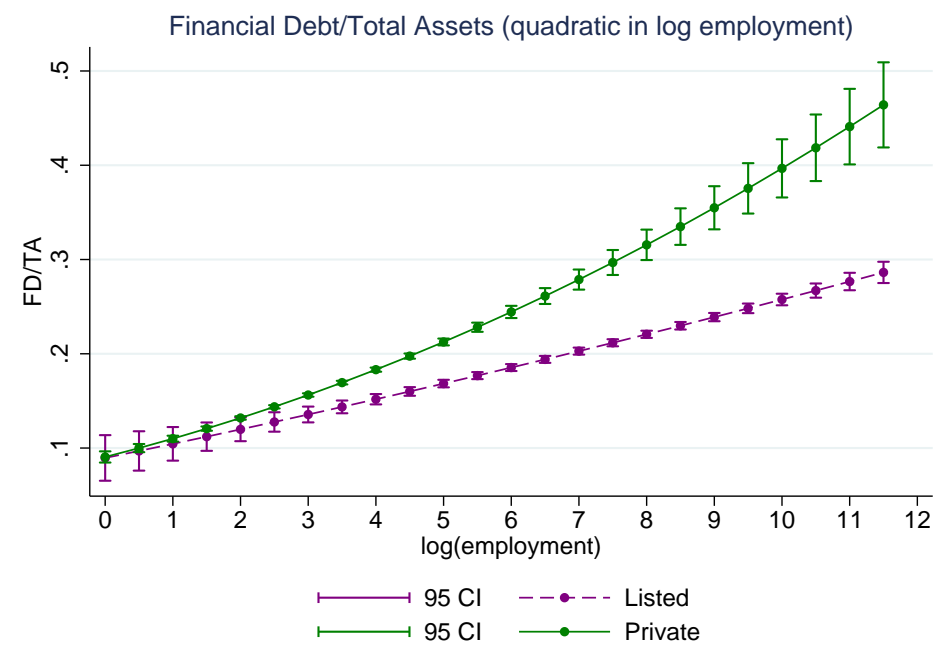

Notes: Uses unbalanced samples of private and publicly-listed firms separately between the years 2005 and 2012. The dependent variable is financial debt/total assets $\left(\mathrm{FD} / \mathrm{TA}_{i t}\right)$. Each line shows the conditional relationship between firm size $\left(\log \left(\mathrm{EMP}_{i t}\right)\right)$ and leverage, where we allow for some flexibility by introducing a quadratic term for employment. The figures condition on $\mathrm{AGE}_{i t}$ to measure firm age; COLLAT $i t$ to measure tangible fixed assets over total assets; $\mathrm{PROFIT}_{i t}$ to measure net income over total assets; and $\mathrm{PROD}_{i t}$ to measure log labor productivity; and a full set of 3-digit industry-year fixed effects. All observations are weighted to adjust for selection into the LOCUS sample.

Figure 11: Quadratic Relationship between STL/TA and Size

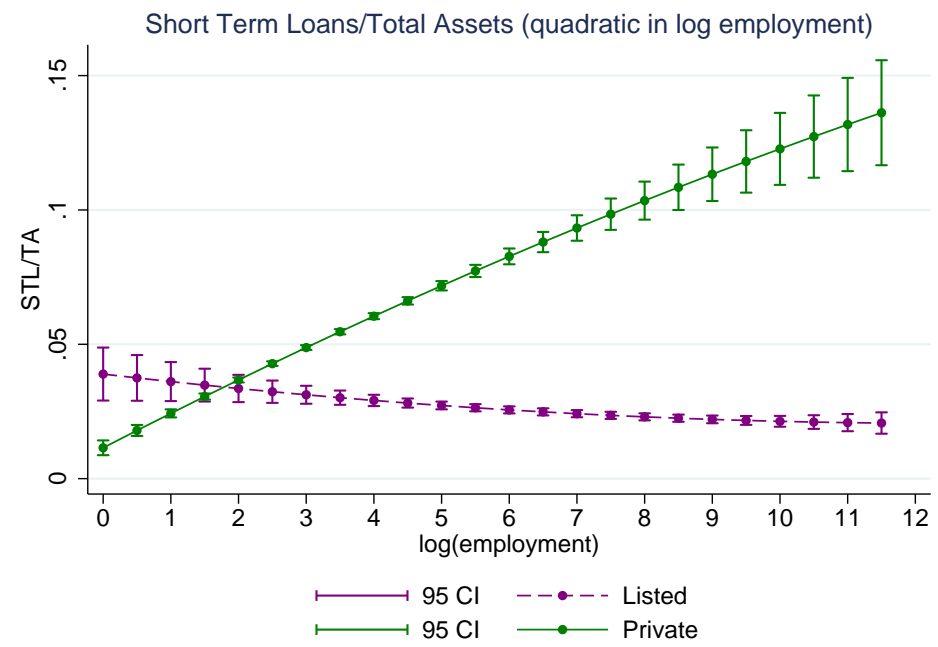

Notes: Uses unbalanced samples of private and publicly-listed firms separately between the years 2005 and 2012. The dependent variable is short-term loans/total assets $\left(\mathrm{STL} / \mathrm{TA}_{i t}\right)$. Each line shows the conditional relationship between firm size $\left(\log \left(\mathrm{EMP}_{i t}\right)\right)$ and leverage, where we allow for some flexibility by introducing a quadratic term for employment. The figures condition on $\mathrm{AGE}_{i t}$ to measure firm age; COLLAT $i t$ to measure tangible fixed assets over total assets; PROFIT $_{i t}$ to measure net income over total assets; and $\mathrm{PROD}_{i t}$ to measure log labor productivity; and a full set of 3-digit industry-year fixed effects. All observations are weighted to adjust for selection into the LOCUS sample. 
Figure 12: Quadratic Relationship between Equity/TA and Size

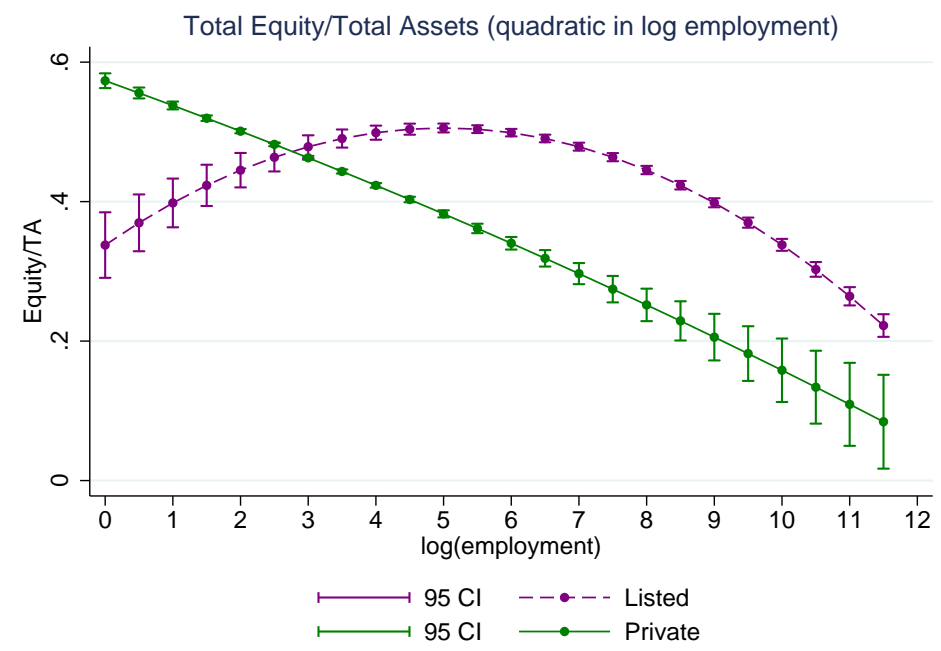

Notes: Uses unbalanced samples of private and publicly-listed firms separately between the years 2005 and 2012. The dependent variable is total equity/total assets $\left(E q u i t y / \mathrm{TA}_{i t}\right)$, where total equity includes both internal and external equity. Each line shows the conditional relationship between firm size $\left(\log \left(\mathrm{EMP}_{i t}\right)\right)$ and leverage, where we allow for some flexibility by introducing a quadratic term for employment. The figures condition on $\mathrm{AGE}_{i t}$ to measure firm age; $\mathrm{COLLAT}_{i t}$ to measure tangible fixed assets over total assets; PROFIT $_{i t}$ to measure net income over total assets; and $\mathrm{PROD}_{i t}$ to measure log labor productivity; and a full set of 3-digit industry-year fixed effects. All observations are weighted to adjust for selection into the LOCUS sample.

Consider next the quadratic specifications in age. Private firms appear to reduce short-term leverage as they age, which is consistent with theories in which entrepreneurs borrow to start their businesses and then pay off their loans as they age (figures 13 and 14). This finding is also consistent with the pattern in figure 15 where private firms raise internal equity as they age, while reducing their short-term debt. The relationship between age and leverage is far weaker and quite flat among public firms in all measures of leverage. Public firms appear to slightly reduce their equity as they age. This behavior is consistent with large public firms being leveraged in long-term debt. 


\section{Figure 13: Quadratic Relationship between FD/TA and Age}

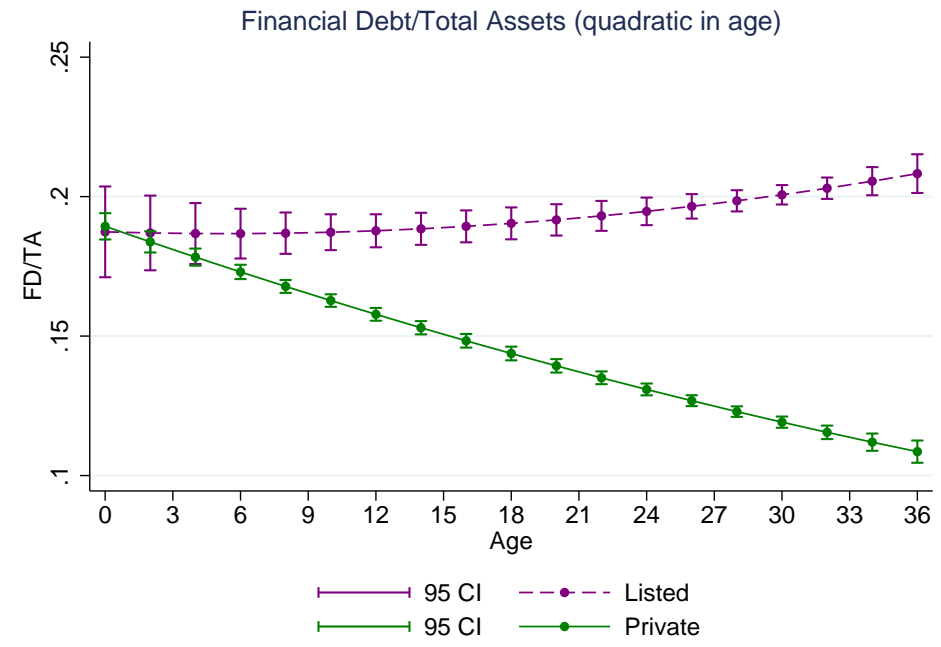

Notes: Uses unbalanced samples of private and publicly-listed firms separately between the years 2005 and 2012. The dependent variable is financial debt/total assets $\left(\mathrm{FD} / \mathrm{TA}_{i t}\right)$. Each line shows the conditional relationship between firm age and leverage, where we allow for some flexibility by introducing a quadratic term for age $\left(\mathrm{AGE}_{i t}\right)$. The figures condition on $\log \left(\mathrm{EMP}_{i t}\right)$ to measure firm size; COLLAT ${ }_{i t}$ to measure tangible fixed assets over total assets; PROFIT $_{i t}$ to measure net income over total assets; and $\mathrm{PROD}_{i t}$ to measure log labor productivity; and a full set of 3-digit industry-year fixed effects. All observations are weighted to adjust for selection into the LOCUS sample.

Figure 14: Quadratic Relationship between STL/TA and Age

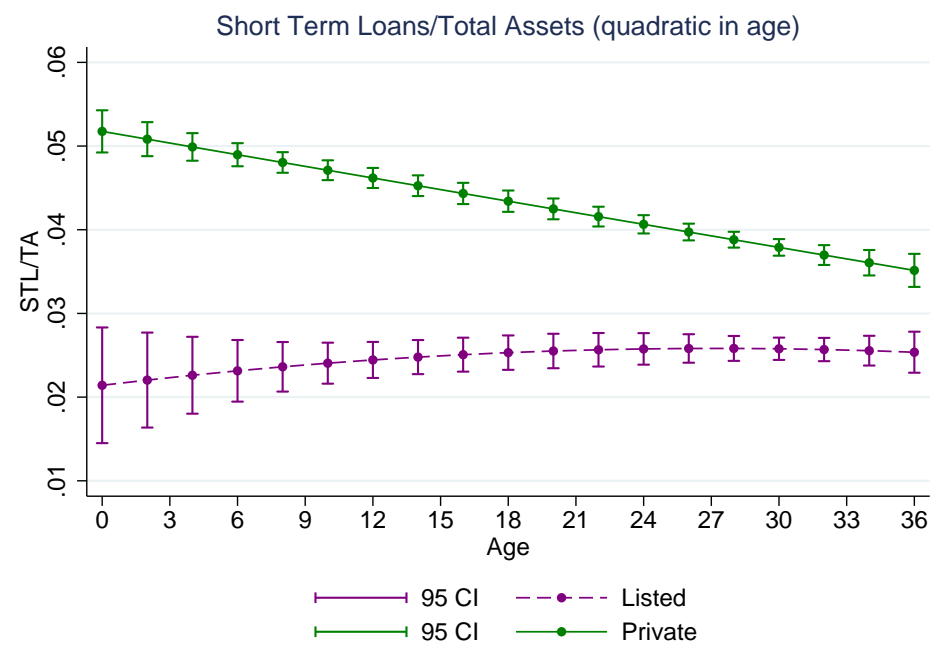

Notes: Uses unbalanced samples of private and publicly-listed firms separately between the years 2005 and 2012. The dependent variable is short-term loans/total assets $\left(\mathrm{STL} / \mathrm{TA}_{i t}\right)$. Each line shows the conditional relationship between firm age and leverage, where we allow for some flexibility by introducing a quadratic term for age $\left(\mathrm{AGE}_{i t}\right)$. The figures condition on $\log \left(\mathrm{EMP}_{i t}\right)$ to measure firm size; COLLAT ${ }_{i t}$ to measure tangible fixed assets over total assets; $\mathrm{PROFIT}_{i t}$ to measure net income over total assets; and $\mathrm{PROD}_{i t}$ to measure log labor productivity; and a full set of 3-digit industry-year fixed effects. All observations are weighted to adjust for selection into the LOCUS sample. 
Figure 15: Quadratic Relationship between Equity/TA and Age

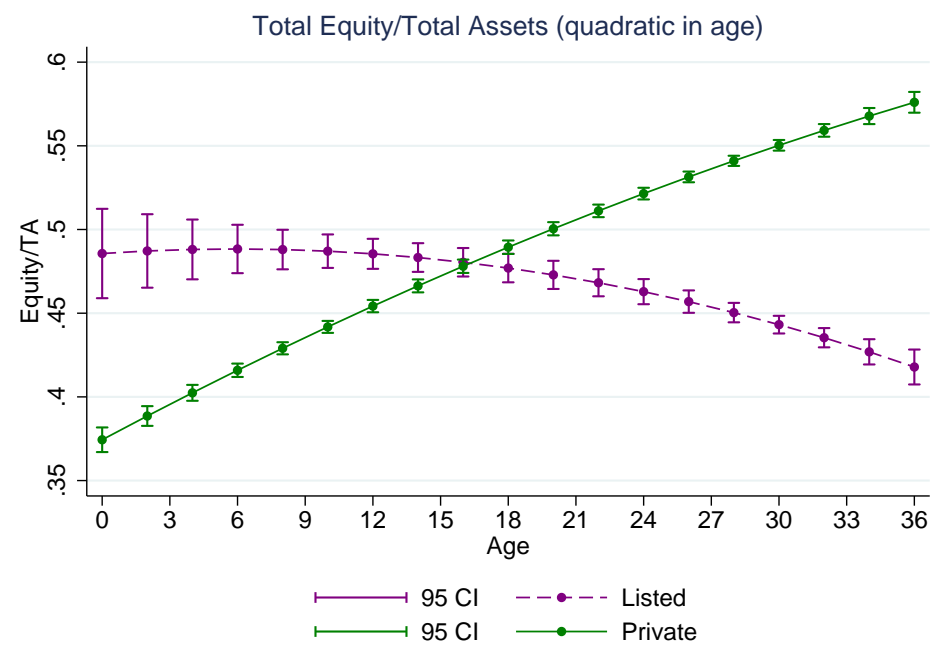

Notes: Uses unbalanced samples of private and publicly-listed firms separately between the years 2005 and 2012. The dependent variable is total equity/total assets $\left(E q u i t y / \mathrm{TA}_{i t}\right)$, where total equity includes both internal and external equity. Each line shows the conditional relationship between firm age and leverage, where we allow for some flexibility by introducing a quadratic term for age $\left(\mathrm{AGE}_{i t}\right)$. The figures condition on $\log \left(\mathrm{EMP}_{i t}\right)$ to measure firm size; COLLAT $i t$ to measure tangible fixed assets over total assets; PROFIT $_{i t}$ to measure net income over total assets; and $\mathrm{PROD}_{i t}$ to measure log labor productivity; and a full set of 3-digit industry-year fixed effects. All observations are weighted to adjust for selection into the LOCUS sample.

\section{Firm Leverage Dynamics During the Great Recession}

Since LOCUS data span the Great Recession, we are able investigate whether the patterns we observe for firm leverage change during the financial shock of 2009-2012. We start by investigating whether the non-linear relationship we examined above changes during the crisis and then consider firm fixed-effects specifications that allow us to account for additional factors influencing leverage during this period.

\subsection{Nonlinear Relationships During the Great Recession}

In figures 16 and 17 we plot the quadratic relationship between size and short-term leverage for private (figure 16) and listed (figure 17) firms before the crisis in 2006 and during the crisis in 2009. To generate this figure and the next, we run a regression of short-term leverage on size, its square, and industry fixed effects, separately for private firms (figure 16) and listed firms (figure 17), and for 2006 and 2009.

$$
S T L E V_{i}=\alpha+\omega_{s}+\beta_{1} \log \left(S I Z E_{i}\right)+\beta_{2} \log \left(S I Z E_{i}\right)^{2}+\epsilon_{i}
$$


where $S T L E V_{i}$ is short-term debt over total assets, $\omega_{S}$ captures industry fixed effects, and $S I Z E_{i}$ is measured by employment. This specification is a close empirical counterpart of the size-dependent collateral constraints in macroeconomic models with financial frictions. ${ }^{26}$

Figure 16 shows that, consistent with our prior results, for private firms there is a positive correlation between size and short-term leverage. The relationships become flatter during the crisis (2009). The relationship between employment and leverage is significantly weaker in 2009 than it was in 2006. In fact, the log-convex relationship in 2006 becomes log-concave in 2009. At larger employment levels, the decline in leverage between 2006 and 2009 is much more pronounced. The pattern is consistent with private firms becoming more financially constrained in 2009 or demanding less bank financing during this period.

In contrast, figure 17 shows that for listed firms the relationship between leverage and size is negative in both 2006 and 2009. Moreover, we do not observe a significant difference in the size-leverage relationship in 2006 and 2009. These results are consistent with our previous findings and suggest that listed firms are less affected by financial frictions both before and during the Great Recession. The results also highlight the importance of data on private firms since not only is the relationship between leverage and size weaker for public firms, it also has the opposite sign.

\footnotetext{
${ }^{26}$ In section $C$ of the appendix, figures 21 and 22 show the results when, in addition to industry fixed effects, we control for labor productivity, collateral, profitability and age. The figures are qualitatively consistent with the figures presented in the main text without the additional controls.
} 
Figure 16: Relationship between short-term leverage and size for private firms (2006 \& 2009)

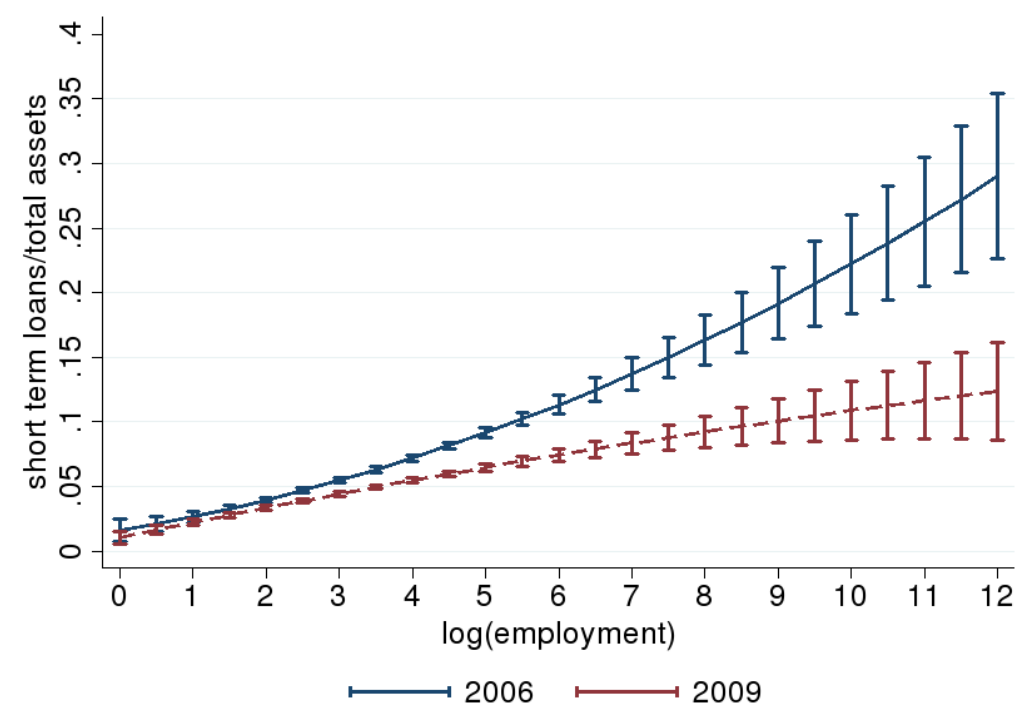

Notes: Uses unbalanced sample of private firms separately for 2006 and 2009. The dependent variable is shortterm leverage (STLEV). Each line shows the relationship between leverage, size (measured by log employment) and size squared, controlling only for a full set of 3-digit industry fixed effects. All observations are weighted to adjust for selection into the LOCUS sample.

Figure 17: Relationship between short-term leverage and size for public firms (2006 \& 2009)

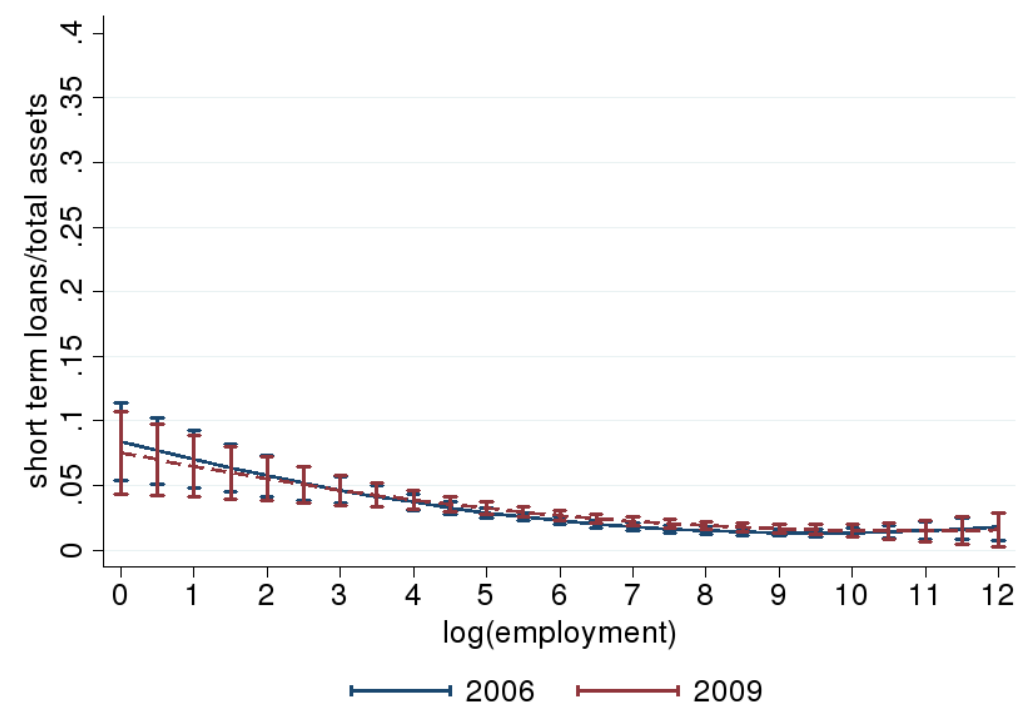

Notes: Uses unbalanced sample of public firms separately for 2006 and 2009. The dependent variable is shortterm leverage (STLEV). Each line shows the between leverage, size (measured by log employment) and size squared, controlling only for a full set of 3-digit industry fixed effects. All observations are weighted to adjust for selection into the LOCUS sample. 


\subsection{Within-Firm Leverage Dynamics Around the Great Recession}

To test whether the cross-section results reported thus far hold within firms over time, we begin with specification (5) and interact regressors with crisis (2008-2009) and post-crisis (20102011) dummies. This strategy rests on the assumption that an exogenous shock to credit availability and financial constraints will affect private and public firms differentially, and the effects may differ in the short-term (crisis) and medium-term (post-crisis). In order to explore potential differences in the estimated relationship across private and public firm, we run the specification separately for each.

$$
\begin{aligned}
L E V_{i t}= & \alpha_{i}+\left(\omega_{s} \times \lambda_{t}\right)+\left(\phi_{c} \times \lambda_{t}\right)+\beta_{1} \log \left(E M P_{i t-1}\right)+ \\
& \beta_{2}\left(\log \left(E M P_{i t-1}\right) \times C R I S I S_{t}\right)+\beta_{3}\left(\log \left(E M P_{i t-1}\right) \times P O S T_{t}\right)+ \\
& \Gamma^{\prime} Z_{i t-1}+\epsilon_{i t}
\end{aligned}
$$

where $\left(\phi_{c} \times \lambda_{t}\right)$ represent county-year fixed effects that absorb regional demand shocks and $\left(\omega_{s} \times \lambda_{t}\right)$ represents industry-year fixed effects that absorb sectoral demand shocks. The CRISIS $_{t}$ dummy is equal to one in 2008 and 2009, and the POST $t_{t}$ dummy is equal to one in 2010 and 2011. $Z_{i t-1}$ contains collateral (COLLAT), profitability (PROFIT), and labor productivity $(P R O D)$ on their own and interacted with each of the dummies. The goal of this

difference in differences (DID) specification is to identify the dynamic response of leverage to an aggregate shock to financing conditions. In doing so, we explore the differences in the response of private versus public firms during crisis and recovery periods. The use of firm fixed effects allow us to identify from "within" variation, rather than cross-sectional variation of firms that is also influenced by the entry and exit of firms during the crisis.

The results in table 6 indicate evidence of deleveraging in the short- and medium-term among privately-held firms, but not listed ones. As established previously, during normal times there is a positive relationship between lagged size and short-term leverage among private firms, which we interpret as evidence of financial constraints. The relationship is insignificant among public firms, as they are relatively unconstrained. The negative significant coefficient on the interaction between the crisis dummy and the lagged employment among privately held firms indicates that when financial shocks hit, large private firms become more constrained. Meanwhile, the interaction is insignificant for public firms who are hit by the same aggregate shock. This finding further supports our interpretation that public firms are 
relatively unconstrained, regardless of their size. The significant negative coefficient on the interaction between the post crisis dummy and lagged employment among privately held firms suggests that the deleveraging process continues even after the financial shock dissipates. In summary, after accounting for demand conditions with county-year and sector-year fixed effects, and other factors that determine leverage, we find that firms that are subject to financial constraints (private firms) are more adversely affected by worsening financial conditions and they undergo a process of deleveraging.

Table 6: Deleveraging: Private and Public Firms

\begin{tabular}{lcc}
\hline & $\begin{array}{c}(1) \\
\text { private }\end{array}$ & $\begin{array}{c}(2) \\
\text { public }\end{array}$ \\
\hline $\log (E M P)_{i t-1}$ & $0.01038^{* * *}$ & 0.002812 \\
& $(0.002199)$ & $(0.003214)$ \\
$\log (E M P)_{i t-1} \times$ CRISIS $_{t}$ & $-0.006105^{* * *}$ & -0.0008865 \\
& $(0.0009193)$ & $(0.0007649)$ \\
$\log (E M P)_{i t-1} \times$ POST $_{t}$ & $-0.01024^{* * *}$ & -0.0008220 \\
& $(0.001139)$ & $(0.0009199)$ \\
\hline Wgts (logit) & $\mathrm{Y}$ & $\mathrm{Y}$ \\
Full Controls & $\mathrm{Y}$ & $\mathrm{Y}$ \\
County-Year FE & $\mathrm{Y}$ & $\mathrm{Y}$ \\
Industry-Year FE & $\mathrm{Y}$ & $\mathrm{Y}$ \\
Firm FE & $\mathrm{Y}$ & $\mathrm{Y}$ \\
Obs. & 99,000 & 13,000 \\
R2 & 0.7319 & 0.6545 \\
\hline \hline
\end{tabular}

Notes: We consider private and publicly-listed firms separately between 2005 and 2012 that have at least four years of data and that active before and during the crisis. The dependent variable is short-term leverage (STLEV). The main regressors - all lagged one period - are log employment $(\log (E M P))$; tangible fixed assets over total assets (COLLAT); net income over total assets (PROFIT); and log labor productivity (PROD). Each of these regressors are also interacted with dummies for the crisis (CRISIS in 2009 and 2010) and post-crisis (POST in 2011 and 2012) periods. Coefficients for employment and its interactions are reported here, but all controls are included. All regressions include a full set of 6-digit industry-year fixed effects, county fixed effects, and firm fixed effects. All observations are weighted to adjust for selection into the LOCUS sample, as detailed in section 3. Standard errors are clustered at the firm level. ${ }^{* * *}, * *$, and ${ }^{*}$ indicates significance at the $1 \%, 5 \%$, and $10 \%$ levels. 


\section{Firm Growth During Normal Times and Great Recession}

To understand the real implications of the financial crisis, we complement our analysis of leverage dynamics during the crisis with an analysis of the relationship between leverage and firm growth during this period. Consider the following firm fixed effects specification:

$$
\begin{aligned}
X_{i t}= & \alpha_{i}+\left(\omega_{s} \times \lambda_{t}\right)+\left(\phi_{c} \times \lambda_{t}\right)++\beta_{1} S T L E V_{i t-1}+ \\
& \beta_{2}\left(S T L E V_{i t-1} \times \text { CRISIS }_{t}\right)+\beta_{3}\left(\text { STLEV }_{i t-1} \times \text { POST }_{t}\right)+ \\
& \boldsymbol{\Gamma}^{\prime} Z_{i t-1}+\epsilon_{i t}
\end{aligned}
$$

where $X$ is $\log$ employment $(\log (E M P))$ or $\log$ revenue $(\log (R E V)) ;\left(\omega_{s} \times \lambda_{t}\right)$ captures industryyear fixed effects, $\left(\phi_{c} \times \lambda_{t}\right)$ captures county-year fixed effects, and $S T L E V_{i t}$ is short-term debt over total assets. STLEV $i t-1$ is interacted with CRISIS $S_{t}$ equal to one in 2008 and 2009 and with $P O S T_{t}$ equal to one in 2010 and 2011. $Z_{i t-1}$ includes, collateral $\left(C O L L A T_{i t-1}\right)$, profitability $\left(P R O F I T_{i t-1}\right)$, and labor productivity $\left(P R O D_{i t-1}\right)$. When the dependent variable is revenue or employment growth, lagged $\log$ revenue $\left(\log \left(R E V_{i t-1}\right)\right)$ or lagged log employment $\left(\log \left(E M P_{t-1}\right)\right.$ are also included as regressors. Each of these additional controls is included on its own and interacted with the crisis and post-crisis dummies. Importantly, county-year fixed effects control for shocks to local demand and sector-year fixed effects control for sectoral demand shocks. We run these specifications separately for private and public firms to account for different responses among private firms to the crisis that might involve unobserved shocks to these firms.

In table 7, we explore the relationship between short-term leverage and employment growth (first two columns) and revenue growth (last two columns) in normal times and during the financial crisis. Lagged short-term leverage is positively associated with both employment and revenue growth during normal times, but only among private firms. However, consistent with the deleveraging results discussed in table 6, when financial conditions worsen and firms are forced to deleverage, the positive relationship between lagged short-term leverage and employment growth turns negative. The attenuation of the positive relationship between leverage and growth occurs in the short-run and only for employment growth. Consistent with the prior evidence that public firms do not undergo deleveraging, the relationship between growth and leverage among public firms is unaffected by the crisis. 
Table 7: Employment and Revenue: Private and Public Firms

\begin{tabular}{lcccc}
\hline \hline & \multicolumn{2}{c}{$\log (E M P)_{i t}$} & \multicolumn{2}{c}{$\log (R E V)_{i t}$} \\
& private & public & private & public \\
\hline STLEV $i t-1$ & $0.06282^{*}$ & -0.07722 & $0.09987^{* *}$ & -0.1221 \\
& $(0.03269)$ & $(0.1224)$ & $(0.04889)$ & $(0.1997)$ \\
& & & & \\
STLEV $V_{i t-1} \times$ CRISIS $_{t}$ & $-0.08033^{* *}$ & -0.01026 & -0.06828 & -0.1027 \\
& $(0.03751)$ & $(0.1720)$ & $(0.07311)$ & $(0.2681)$ \\
STLEV $i t-1 \times$ POST $_{t}$ & -0.0005963 & -0.2501 & 0.1089 & -0.2526 \\
& $(0.04987)$ & $(0.1868)$ & $(0.07043)$ & $(0.2807)$ \\
\hline Wgts (logit) & $\mathrm{Y}$ & $\mathrm{Y}$ & $\mathrm{Y}$ & $\mathrm{Y}$ \\
Full Controls & $\mathrm{Y}$ & $\mathrm{Y}$ & $\mathrm{Y}$ & $\mathrm{Y}$ \\
County-Year FE & $\mathrm{Y}$ & $\mathrm{Y}$ & $\mathrm{Y}$ & $\mathrm{Y}$ \\
Industry-Year FE & $\mathrm{Y}$ & $\mathrm{Y}$ & $\mathrm{Y}$ & $\mathrm{Y}$ \\
Firm FE & $\mathrm{Y}$ & $\mathrm{Y}$ & $\mathrm{Y}$ & $\mathrm{Y}$ \\
Obs. & 99,000 & 13,000 & 99,000 & 13,000 \\
R2 & 0.9738 & 0.9903 & 0.9591 & 0.9801 \\
\hline \hline
\end{tabular}

Notes: We consider private and publicly-listed firms separately between 2005 and 2012 that have at least four years of data and that active before and during the crisis. The dependent variables are log employment (columns 1-2) and log revenue (columns 3-4). The main regressors - all lagged one period - are short-term leverage (STLEV); tangible fixed assets over total assets (COLLAT); net income over total assets (PROFIT); and log labor productivity (PROD). Each of these regressors are also interacted with dummies for the crisis (CRISIS in 2009 and 2010) and post-crisis (POST in 2011 and 2012) periods. Coefficients for STLEV and its interactions are reported here, but all controls are included. All regressions include a full set of 6-digit industry-year fixed effects, county fixed effects, and firm fixed effects. All observations are weighted to adjust for selection into the LOCUS sample, as detailed in section 3 . Standard errors are clustered at the firm level. ${ }^{* * *},{ }^{* *}$, and ${ }^{*}$ indicates significance at the $1 \%, 5 \%$, and $10 \%$ levels.

\section{Sectoral Growth During Normal Times and Great Recession}

In this section, we aggregate our data and run the following specifications at the sector-year level to explore whether leverage dynamics are associated with aggregate boom-bust credit cycles at the sector level.

$$
\begin{aligned}
\log \left(S O_{s t}\right)= & \alpha_{s}+\lambda_{t}+\beta_{1} S T L E V_{s t-1}+\beta_{2}\left(S T L E V_{s t-1} \times \text { CRISIS }_{t}\right)+ \\
& \beta_{3}\left(S T L E V_{s t-1} \times \text { POST }_{t}\right)+\epsilon_{s t}
\end{aligned}
$$

where $S O$ is sector-level employment or revenue and $\alpha_{s}$ and $\lambda_{t}$ are sector and year fixed effects. Employment data are available at the establishment and firm level, and revenue data 
are only available at the firm level. To aggregate revenue (log rev (firm)) and employment (log emp (firm)) to the sector-level from firm-level data, we assign each firm to the industry in which it has the most employment. We also aggregate employment to the sector-level from establishment-level data using the industry to which each establishment is assigned (log emp (est)). STLEV $V_{s t}$ is calculated at the sector level as the activity-weighted average short-term leverage in a particular sector-year. The activity weights take into account both the sampling weight and employment share of the firm in the sector-year. Since financial data are only available at the firm level, we assign each firm to the industry in which it has the most employment. To mirror our firm-level analysis, we also explore the differential effect of leverage on sector growth during normal (2005-2007), crisis (2008-2009), and recovery (2010-2011) periods by including CRISIS $t_{t}$ and $\mathrm{POST}_{t}$ dummies interacted with the regressors. These regressions test whether firm-level financial frictions have implications for aggregate activity and growth.

Consistent with our finding in table 7, table 8 and figure 18 shows that prior to the crisis, sectors with higher lagged short-term leverage have higher employment. However, as financial conditions worsens in 2009, those sectors with higher lagged short-term leverage have lower employment, which could be a consequence of firms in highly leveraged sectors deleveraging. Notice that we identify from within variation and hence these results reflect the dynamics of employment and revenue growth rather than cross-sectoral leverage differences. Clearly, firms' leveraging and deleveraging have important effects on aggregate boom-bust cycles through sectoral growth dynamics. 
Figure 18: Sector-level Employment and Leverage (2006 \& 2009)
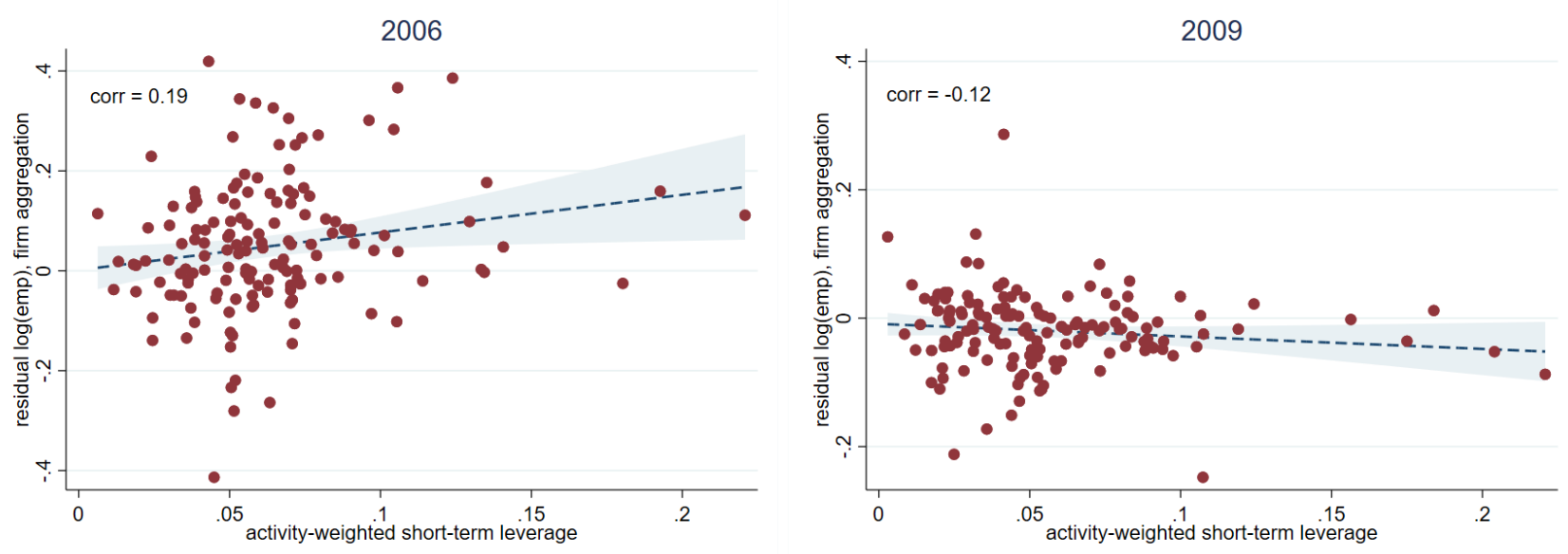

Notes: This figure compares the relationship between employment and short-term leverage in normal times (2006) and the crisis (2009). The $x$-axis is the 4-digit NAICS level activity weighted average short-term leverage in each year. The activity weights take into account the sampling weight and employment of each firm. The $\mathrm{y}$-axis is the residual log employment at the 4-digit NAICS level. Fist, each firm is assigned a 4-digit NAICS based on its modal employment. Second, this employment is aggregated to the sector-year level. Finally, the sector-level employment is regressed on industry fixed effects using pooled sector-year data between 2006 and 2012 and the residual of this regression is plotted on the y-axis in 2006 (left) and 2009 (right).

Table 8: Sector-Level Employment, Revenue, \& Leverage: Normal \& Crisis Times

(1)

(2)
(3)

\begin{tabular}{|c|c|c|c|}
\hline & $\log$ emp (est) & $\log$ emp (firm) & log rev (firm) \\
\hline \multirow[t]{2}{*}{$S T L E V_{s t-1}$} & $0.7093^{* *}$ & $0.6893^{*}$ & $1.732^{* *}$ \\
\hline & $(0.3565)$ & $(0.4061)$ & (0.7303) \\
\hline \multirow{2}{*}{$S T L E V_{s t-1} \times C_{R I S I S}$} & $-0.7321^{* * *}$ & $-0.8261^{* * *}$ & $-2.098^{* * *}$ \\
\hline & $(0.2615)$ & $(0.2698)$ & $(0.6208)$ \\
\hline \multirow{2}{*}{$S T L E V_{s t-1} \times \operatorname{POST}_{t}$} & $-0.9285^{* * *}$ & $-1.071^{* * *}$ & -0.5580 \\
\hline & $(0.3479)$ & (0.4078) & $(0.8263)$ \\
\hline Industry FE & Y & Y & Y \\
\hline Year FE & Y & Y & Y \\
\hline Obs & 1029 & 1029 & 1029 \\
\hline R2 & 0.9919 & 0.9892 & 0.9752 \\
\hline
\end{tabular}

Notes: We consider consider regressions at the 4-digit NAICS-year level between 2006 and 2012. The dependent variables are log employment derived from establishment level data (column 1), log employment derived from firm level data (column 2), and log revenue derived from firm level data (column 3). The main regressors are one period lagged activity-weighted average short-term leverage (STLEV), - where the activity weights account for sampling weights and firm employment - and the interactions of this variable with a dummy variable equal to one in 2009 and 2010 (CRISIS) and a dummy variable equal to one in 2011 and 2012 (POST). All regressions include industry and year fixed effects. Standard errors are clustered at the 4-digit industry level. ${ }^{* * *}{ }^{* *}$, and * indicates significance at the $1 \%, 5 \%$, and $10 \%$ levels,respectively. 


\section{Conclusion}

Privately held firms account for more than half of the U.S. gross output, and nearly two-thirds of employment. Despite their importance, the patterns of financing have remained relatively unexplored for these firms, due to lack of large datasets that contain detailed information on their finances and real outcomes. We fill this gap by creating a new dataset, LOCUS, that links firm balance sheets with real firm outcomes, such as revenue and employment growth, for a large sample of private firms. The dataset also covers publicly-traded firms in the United States, and enables a comparison of the behavior of private versus public firms.

We show three sets of results. First, firm financing and leverage are endogenous to firm life cycle and this fact can bee seen when we focus on private firms but will be missed if we only focus on public firms. Larger and younger firms have higher leverage. These normal time leverage dynamics lead to important differences in response to financial shocks that tighten economy-wide credit conditions. One such shock is the episode of Great Recession of 20072009. Using this shock we show that there is extensive firm heterogeneity in response to the crisis and this heterogeneity is linked to the heterogeneity in firm leverage. Firms with high leverage before the crisis, had to cut down employment and revenue more during the crisis in order to delever. And last but not least, these leverage dynamics before and after the crisis affect aggregate growth dynamics through sectors' exposure to leveraged firms. Sectors with more firms who were highly levered, grew more before the crisis but also contract more during and after the crisis. These results highlight the importance of understanding the determinants and dynamics of private firms' financing for economy wide outcomes in terms of aggregate employment and revenue growth in the U.S. 


\section{References}

Ajello, Andrea, "Financial Intermediation, Investment Dynamics, and Business Cycle Fluctuations," American Economic Review, 2016, 106 (8), 2256-2303.

Albuquerque, Rui and Hugo Hopenhayn, "Optional Lending Contracts and Firm Dynamics," Review of Economic Studies, 2004, 71 (2), 285-315.

Alfaro, Ivan, Nicholas Bloom, and Xiaoji Lin, "The Real and Financial Impact of Uncertainty Shocks," 2016. Unpublished draft, Stanford University.

Ang, James, Rebel Cole, and Daniel Lawson, "The Role of Owner in Capital Structure Decisions: An Analysis of Single-Owner Corporations," Journal of Entrepreneurial Finance, 2010, $14(3), 1-36$.

Asker, John, Joan Farre-Mensa, and Alexander Ljungqvist, "Corporate Investment and Stock Market Listing: A Puzzle?," Review of Financial Studies, 2015, 28 (2), 342-390.

Bassetto, Marco, Marco Cagetti, and Mariacristina De Nardi, "Credit Crunches and Credit Allocation in a Model of Entrepreneurship," Review of Economic Dynamics, 2015, 18 (1), 53 76.

Begenau, Juliane and Juliana Salomao, "Firm Financing over the Business Cycle," 2015. Working Paper.

Berger, Allen and Gregory Udell, "The Economics of Small Business Finance: The Roles of Private Equity and Debt Markets in the Financial Growth Cycle," Journal of Banking and Finance, 1998, 22.

Bernanke, Ben and Simon Gilchrist, "The Financial Accelerator in a Quantitative Business Cycle Framework," in J.B. Taylor and M. Woodford, eds., Handbook of Macroeconomics, Vol. 1 of Handbooks in Economics, Elsevier, 1999, chapter 21, pp. 1341-1393.

Bernstein, Shai, Xavier Giroud, and Richard Townsend, "The Impact of Venture Capital Monitoring," Journal of Finance, 2016, 71 (4), 1591-1622.

Brown, David and John Earle, "Finance and Growth at the Firm Level: Evidence from SBA Loans," Journal of Finance, 2017, 72 (3), 1039-1080. 
Brunnermeier, Markus K. and Yuliy Sannikov, "A Macroeconomic Model with a Financial Sector," American Economic Review, 2014, 104 (2), 379-421.

Buera, Francisco and Benjamin Moll, "Aggregate Implications of a Credit Crunch: The Importance of Heterogeneity," American Economic Journal: Macroeconomics, 2015, 7 (3), 1-42.

- and Yongseok Shin, "Financial Frictions and the Persistence of History: A Quantitative Explanation," Journal of Political Economy, 2013, 121 (2), 221-272.

Cagetti, Marco and Mariacristina De Nardi, “Entrepreneurship, Frictions, and Wealth," Journal of Political Economy, 2006, 114 (5), 835-870.

Chari, V.V., Lawrence J. Christiano, and Patrick Kehoe, "The Gertler-Gilchrist Evidence on Small and Large Firm Sales," Mimeo, University of Minnesota 2013.

Chodorow-Reich, Gabriel, “The Employment Effects of Credit Market Disruptions: Firm Level Evidence from the 2008-2009 Financial Crisis," Quarterly Journal of Economiics, 2014, 129 (1), $1-59$.

- and Antonio Falato, "The Loan Covenant Channel: How Bank Health Transmits to the Real Economy," Working Paper 23879, National Bureau of Economic Research 2017.

Clementi, Gian and Hugo Hopenhayn, "A Theory of Financing Constraints and Firm Dynamics," Quarterly Journal of Economics, 2006, pp. 229-265.

Cole, Rebel, "What Do We Know about the Capital Structure of Privately Held US Firms? Evidence from the Survey of Small Business Finance," Financial Management, 2013, pp. 777813.

Cooley, Thomas and Vincenzo Quadrini, "Financial Markets and Firm Dynamics," American Economic Review, 2001, 91 (5), 1286-1310.

_, Ramon Marimon, and Vincenzo Quadrini, “Aggregate Consequences of Limited Enforceability," Journal of Political Economy, 2004, 112 (4), 817-847.

Covas, Francisco and Wouter Den Haan, "The Role of Debt and Equity Finance Over the Business Cycle," Economic Journal, 2012, 122, 1262-1286. 
Crouzet, Nicolas and Neil Mehrotra, "Small and Large Firms over the Business Cycle," 2017. Working Paper.

Custodio, Claudio, Miguel Ferreira, and Luis Laureano, "Why are US firms uisng more shortterm debt?," Journal of Financial Economics, 2012.

Davis, Steven, John Haltiwanger, and Scott Schuh, "Small Business and Job Creation: Dissecting the Myths and Reassessing the Facts," Small Business Economics, 1996, 8 (4), 297-315.

_ , _ , Kyle Handley, Ron Jarmin, Josh Lerner, and Javier Miranda, "Private Equity, Jobs and Productivity," American Economic Review, 2014, 104 (12), 3956-3990.

_ , _ , Ron Jarmin, and Javier Miranda, "Volatility and Dispersion in Business Growth Rates: Publicly Traded versus Privately Held Firms," in Daron Acemoglu, Kenneth Rogoff, and Michael Woodford, eds., NBER Macroeconomic Annual, Vol. 21 of NBER Macroeconomic Annual 2006, chapter 2, pp. 107-180.

Diamond, Douglas, "Debt Maturity Structure and Liquidity Risk," Quarterly Journal of Economics, 1991, 106 (3), 709-737.

Dinlersoz, Emin, Henry Hyatt, and Hubert Janicki, “Who Works for Whom? Worker Sorting in a Model of Entrepreneurship with Heterogeneous Labor Markets," 2017. Unpublished draft, U.S. Census Bureau.

Evans, David and Boyan Jovanovic, "An Estimated Model of Entrepreneurial Choice under Liquidity Constraints," Journal of Political Economy, 1989, 97 (4), 808-827.

Farre-Mensa, Joan and Alexander Ljungqvist, "Do Measures of Financial Constraints Measure Financial Constraints," Review of Financial Studies, 2016, 29 (2), 271-308.

Fort, Teresa C., John Haltiwanger, Ron S. Jarmin, and Javier Miranda, "How Firms Respond to Business Cycles: The eRole of Firm Age and Firm Size," IMF Economic Review, 2013.

Gertler, Mark and Simon Gilchrist, "Monetary Policy, Business Cycles, and the Behavior of Small Manufacturing Firms," Quarterly Journal of Economics, 1994, 109 (2), 309-340.

Gilchrist, Simon, Michael Siemer, and Egon Zakrajsek, "The Real Effects of Credit Booms and Busts," Working Paper 2018. 
Giroud, Xavier and Holger Mueller, "Firm Leverage, Consumer Demand, and Unemployment during the Great Recession," Quarterly Journal of Economics, 2017, pp. 271-316.

Gopinath, Gita, Sebnem Kalemli-Ozcan, Loukas Karabarbounis, and Carolina VillegasSanchez, "Capital Allocation and Productivity in South Europe," Quarterly Journal of Economics, 2017, 132 (4), 1915-1967.

Haltiwanger, John, Ron Jarmin, Rob Kulick, and Javier Miranda, “High Growth Young Firms: Contributiton to Jobs, Output, and Productivity Growth," in Haltiwanger, Hurst, Miranda, and Schoar, eds., Measuring Entrepreneurial Businesses: Current Knowledge and Challenges, NBER/University of Chicago Press, 2017.

Hart, Oliver and John Moore, "A Theory of Debt Based on the Inalienability of Human Capital," Quarterly Journal of Economics, 1994, 109, 841-879.

Holmstrom, Bengt and Jean Tirole, "Financial Intermediation, Loanable Funds, and the Real Sector," Quarterly Journal of Economics, 1997, 112 (3), 663-691.

Hopenhayn, Hugo, “Entry, Exit, and Firm Dynamics in Long Run Equilibrium," Econometrica, 1982, 60 (5), 1127-1150.

Huynh, Kim, Teodora Paligorova, and Robert Petrunia, “Debt financing in private and public firms," Annals of Finance, 2018, pp. 1-23.

Jeenas, Priit, "Monetary Policy Shocks, Financial Structure, and Firm Activity: A Panel Approach," Working Paper 2018.

Jermann, Urban and Vincenzo Quadrini, “Macroeconomic Effects of Financial Shocks," American Economic Review, 2012, 102 (1), 238-271.

Jovanovic, Boyan, "Selection and Evolution of Industry," Econometrica, 1982, 50 (3), 649-670.

Khan, Aubhik and Julia Thomas, "Credit Shocks and Aggregate Fluctuations in an Economy with Production Heterogeneity," Journal of Political Economy, 2013, 121 (6), 1055-1107.

Kiyotaki, Nobuhiro and John Moore, "Credit Cycles," Journal of Political Economy, 1997, 105 (2), 211-248. 
Kudlyak, Marianna and Juan M. Sanchez, "Revisiting the Behavior of Small and Large Firms during the 2008 Financial Crisis," Journal of Economic Dynamics and Control, 2017, 77, 48-69.

Lemmon, Michael, Michael Roberts, and Jaime Zender, "Back to the Beginning: Persistence and the Cross-Section of Corporate Capital Structure," Journal of Finance, 2008, 63 (4), 15751608.

McCue, Kristen, "Matching Compustat Data to the SSEL," Mimeo, Center for Economic Studies, U.S. Census Bureau 2003.

Mendoza, Enrique, "Sudden Stops, Financial Crises, and Leverage," American Economic Review, 2010, 100 (5), 1941-1966.

Moll, Benjamin, "Productivity Losses from Financial Frictions: Can Self-Financing Undo Capital Misallocation?," American Economic Review, 2014, 104 (10), 3186-3221.

Moscarini, Giuseppe and Fabien Postel-Vinay, "The Contribution of Large and Small Employers to Job Creation at Time of High and Low Unemployment," American Economic Review, 2012, 102 (6), 2509-2539.

Nikolov, Boris, Lukas Schmid, and Roberto Steri, “Dynamic Corporate Liquidity,” 2017. Working Paper.

Ottonello, Pablo and Thomas Winberry, "Financial Heterogeneity and the Investment Channel of Monetary Policy," 2018. Working Paper.

Petersen, Mitchell and Raghuram G. Rajan, "Does Distance Still Matter? The Information Revolution in Small Business Lending," Journal of Finance, 2002, 57 (6), 2533-2570.

Quadrini, Vincenzo, "Entrepreneurship, Saving, and Social Mobility," Review of Economic Dynamics, 2000, 3 (1), 1-40.

Rajan, Raghuram and Luigi Zingales, "What Do We Know about Capital Structure? Some Evidence from International Data," Journal of Finance, 1995, 50 (5), 1421-1460.

Robb, Alicia and David Robinson, "The Capital Structure Decisions of New Firms," Review of Financial Studies, 2012, 1 (1). 
Schliefer, Andrei and Robert W. Vishny, "Liquidation Value and Debt Capacity: A Market Equilibrium Approach," Journal of Finance, 1992, 47 (4), 1343-1366.

Virgiliu, Midrigan and Daniel $\mathrm{Xu}$, "Finance and Misallocation: Evidence from Plant-Level Data," American Economic Review, 2014, 104 (2), 422-458.

Whited, Toni and Guojun Wu, "Financial Constraints Risk," Review of Financial Studies, 2006, 19 (2), 531-559.

Zeltin-Jones, Ariel and Ali Shourideh, "External Financing and the Role of Financial Frictions over the Business Cycle: Measurement and Theory," 2016. Working Paper. 


\section{A Comparison of LOCUS and QFR data}

Although QFR surveys both small and large firms in the manufacturing sector, LOCUS has better coverage of small firms. To be consistent with figures 3 and 4 , we focus on the year 2010. Since coverage in the QFR is greatest in the manufacturing sector, we also focus on this sector in the LBD, Compustat, and LOCUS. In the figure 19, we plot the distribution of real revenue, which is available for all four data sources. The three non-LBD data sources have a greater mass of large firms than the LBD. While QFR contains smaller firms than Compustat, the LOCUS distribution of real revenue is closer that of the LBD than QFR.

In figure 20, we plot the distribution of log real total assets for the three data sources where this variable is available - Compustat, LOCUS and QFR. Again, we see that while QFR's coverage of small firms is better than Compustat, it is worse than LOCUS. Moreover, LOCUS contains data on both small and large firms in sectors outside of manufacturing, while QFR surveys only large firms outside of manufacturing.

Figure 19: Comparison of Revenue Distributions (2010, Manufacturing Sector)

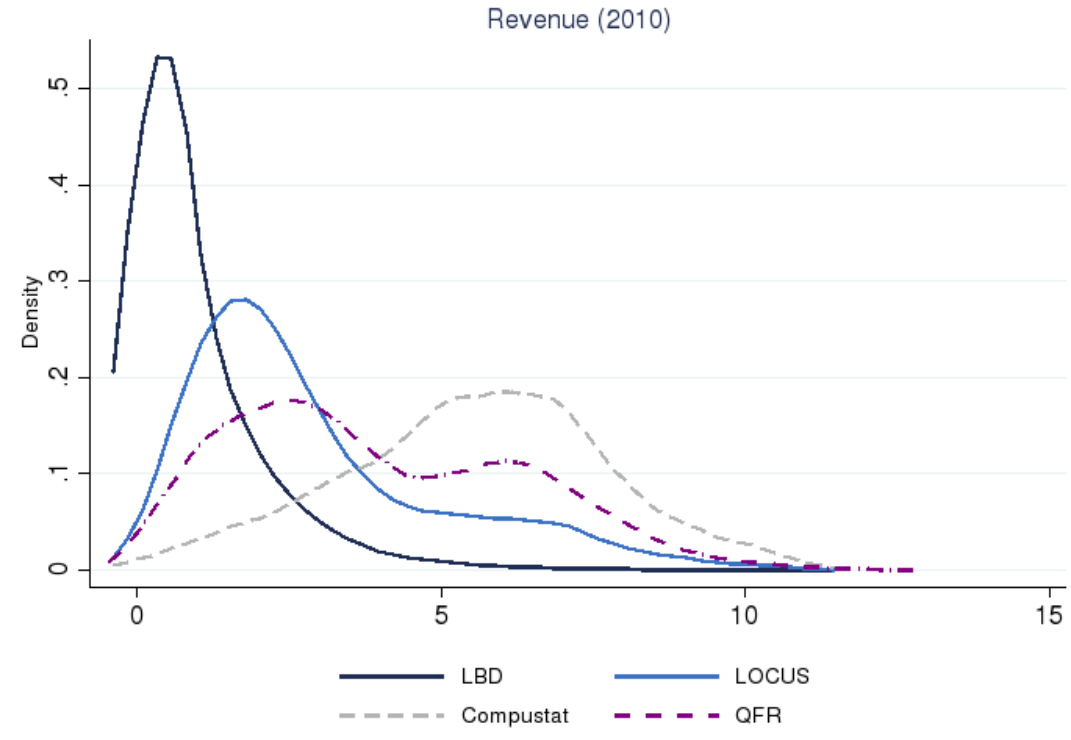

Notes: This figure compares the distribution of firm-level revenue in the manufacturing sector across four samples in 2010. The first sample contains firms in the LBD, the second contains LOCUS (both private and public firms), the third contains Compustat firms (public firms), and the last are firms in the Quarterly Financial Report (QFR). The distributions are generated using kernel density estimation and the top and bottom tails have been removed to comply with disclosure requirements. 
Figure 20: Comparison of Total Assets Distributions (2010, Manufacturing Sector)

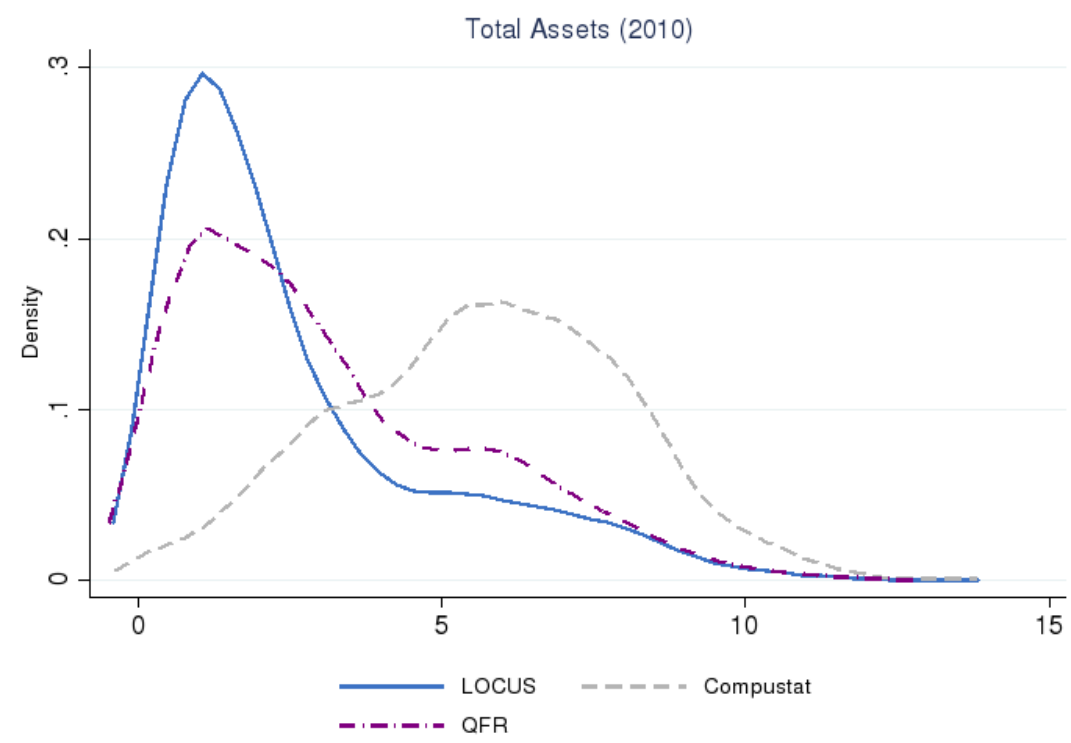

Notes: This figure compares the distribution of firm-level total assets in the manufacturing sector across three samples in 2010. The first sample contains firms in LOCUS (both private and public firms), the second contains only Compustat firms (public firms), and the last contains firms in the Quarterly Financial Report (QFR). The distributions are generated using kernel density estimation and the top and bottom tails have been removed to comply with disclosure requirements.

\section{B Matching Procedure}

Orbis and Compustat contain entity name, employer identification number (EIN), city, state and zip code; Compustat additionally contains street address information. LBD records can be linked to the business register, which contains firm name, EIN, street address, city, state and zip code. The LBD/SSEL is linked to Orbis and Compustat separately and annually using a multi-stage probabilistic matching procedure similar to that used in McCue (2003) to construct the Compustat-SSEL bridge that is available through 2005.

In all, there are nine stages to our matching procedure. In the first stage, Orbis and Compustat records that have EIN information are matched to the LBD/SSEL based on this variable. All remaining unmatched records, along with those that do not contain EIN but contain location information, are then matched based on fuzzed entity name, address, city, and exact state and zip code. ${ }^{27}$ For Compustat the second stage matches records based on fuzzed name street address, city and exact state. This second stage cannot be implemented for Orbis because street address is unavailable. The third stage matches records based on fuzzed name and city, and

\footnotetext{
${ }^{27}$ The term fuzzed refers to our use of the DQMATCH procedure implemented in SAS.
} 
exact state and zip code. Stages 4 through 6 rely on different combinations of fuzzed entity name and two location identifiers. Finally, stages 7 through 9 use fuzzed entity name and one location identifier. In contrast to McCue (2003), we do not base any matches solely on fuzzed entity name.

Due to the probabilistic nature of the matching, one Orbis/Compustat record will initially be linked to multiple records in the LBD/SSEL. First, we clean the annual matched data. Each potential match is evaluated based on the similarity in location (zip code, city and state), name, and industry code between the Orbis/Compustat record and its match in the LBD/SSEL. We rely on the Jaro-Winkler distance to measure the similarity between each matched name and city. ${ }^{28}$ For each Orbis or Compustat record, only the highest quality match is retained. This first stage of cleaning results in a dataset in which each record, corresponding to a firm-year observation, in Orbis/Compustat is matched to just one record in LBD/SSEL.

We further clean our matches to obtain a panel cross-walk between Orbis/Compustat entities and firms in the LBD/SSEL by taking advantage of the information on matches over time. First, if an Orbis/Compustat entity consistently matches with only one LBD/SSEL firm, but a match was not achieved for all the years for which we have records, the LBD/SSEL firm identifier is imputed. Second, if an Orbis/Compustat entity matched to multiple firms over time, we keep the firm(s) that were matched with the strictest criteria. Third, if an Orbis/Compustat entity still matches to multiple firms over time based on the same criteria, we keep the firm(s) with the highest overall match score. One additional imputation is done for Compustat. A key difference between Orbis and Compustat is that the entity name and location variables in Compustat are static over time and represent information provided by the entity in its latest filing. As a result, for Compustat firms if multiple firm matches remain after the previous steps have been implemented, we take the latest match and impute it backwards.

As a final check, we bring in firm employment and age information from the LBD. For records in which we imputed the LBD/SSEL firm due to multiple firm matches over time, we only consider the imputation valid if we observe firm employment or age in the year the imputation was made. We revert to the original firm match if the imputation is considered invalid. After this step is implemented we still have cases where one Orbis/Compustat entity is matched to multiple firms over time. This could be picking up firm-level reorganization

\footnotetext{
${ }^{28}$ We thank Mark Kutzbach at the U.S. Census Bureau for giving us access to the Jaro-Winkler comparator code.
} 
and/or mergers and acquisitions. In order to ensure that multiple matches are not driven by the probabilistic nature of our matching, we drop cases where an Orbis/Compustat entity matched with more than three LBD firms. Very few observations are dropped by this criteria, and our implicit assumption is that in the 11 years used in our matching we don't expect a firm to go through more than three reorganizations. Finally, we drop cases where a firm matches with more than two entities and the matches are based on fuzzed name and less than three location criteria.

After these steps have been implemented, we end up with two datasets. Our Orbis-LBD/SSEL data which contains nearly 78 percent of underlying Orbis entity-year observations, corresponding to 70 percent of entities in the underlying Orbis data. 76 percent of these matches are based on EIN, while an additional 18 percent are based on name, zip code, city and state. Our Compustat-LBD/SSEL data contains 84 percent of underlying Compustat entity-year observations, corresponding to 79 percent of entities in the underlying Compustat data. The match rate at the firm-level is consistent with the match rate of Compustat firms reported in McCue (2003) once we take into account that none of our matches are made solely on fuzzed name. 75 percent of these matches are based on EIN, while an additional 6 percent are based on name and full address information.

As a final step in constructing LOCUS, we combine Orbis-LBD/SSEL and CompustatLBD/SSEL matched datasets to ensure that we do not double count any publicly-listed firms that are in both datasets. We begin by matching the two datasets. If a firm appears in both matched datasets, we give preference to the the data source (Orbis or Compustat) with the longest sample period. Since all Compustat financial statements are consolidated, we expect that only one Compustat entity matches to a LBD firm in each year. In a very limited number of cases more than one Compustat entity matches to one LBD firm in a year, and in all of these cases the match is based either on EIN or fuzzed name and three location variables. Because these matches are of high quality, they most likely represent a reorganization. A visual inspection of the balance sheet in these cases leads us to favor summing financial variables across the Compustat entities in the year we observe the reorganization. Orbis entities file unconsolidated financial statements. As a result, we expect that several Orbis entities may match to a single LBD firm in one year. Since we are interested in tracking firm performance over time, we may be concerned about changes in the composition of Orbis entities reporting balance sheets for the same firm over time. To address this concern, we only keep the set of Orbis enti- 
ties associated with a particular firm that consistently report their balance sheets. The sample from which we draw on for our regression analysis consists of nearly 198,000 unique firms, 97 percent of which are privately held.

\section{Conditional Nonlinear Relationships During the GR}

The figures in this section are generated by regressing short-term leverage on size, size squared, age, collateral, profitability, labor productivity and industry fixed effects separately for private and listed firms in 2006 and 2009.

$$
\begin{aligned}
S T L E V_{i}= & \alpha+\omega_{s}+\beta_{1} \log \left(\operatorname{SIZE}_{i}\right)+\beta_{2} \log \left(\operatorname{SIZE}_{i}\right)^{2}+\beta_{3} A G E_{i}+ \\
& \beta_{4} \text { COLLAT }_{i}+\beta_{5} \text { PROFIT }_{i}+\beta_{6} \text { PROD }_{i}+\epsilon_{i}
\end{aligned}
$$

where $S T L E V_{i}$ is short-term debt over total assets, $\omega_{s}$ captures industry fixed effects, $S I Z E_{i}$ is measured by employment, $A G E_{i}$ is firm age, $C O L L A T_{i}$ is total fixed assets over total assets, PROFIT $i$ is net income over total assets, and $P R O D_{i}$ is total employment over revenue.

The results for private firms are reported in figure 21 and for listed firms in figure 22. Consistent with our findings in section 5.1, the figures here show a positive relationship between short-term leverage and size among private firms that becomes significantly weaker during the Great Recession when size is measured by employment. In contrast, the relationship between leverage and size is negative among listed firms and we do not find a significant change in the strength of that relationship between 2006 and 2009. 
Figure 21: Conditional Relationship between short-term leverage and size for private firms (2006 \& 2009)

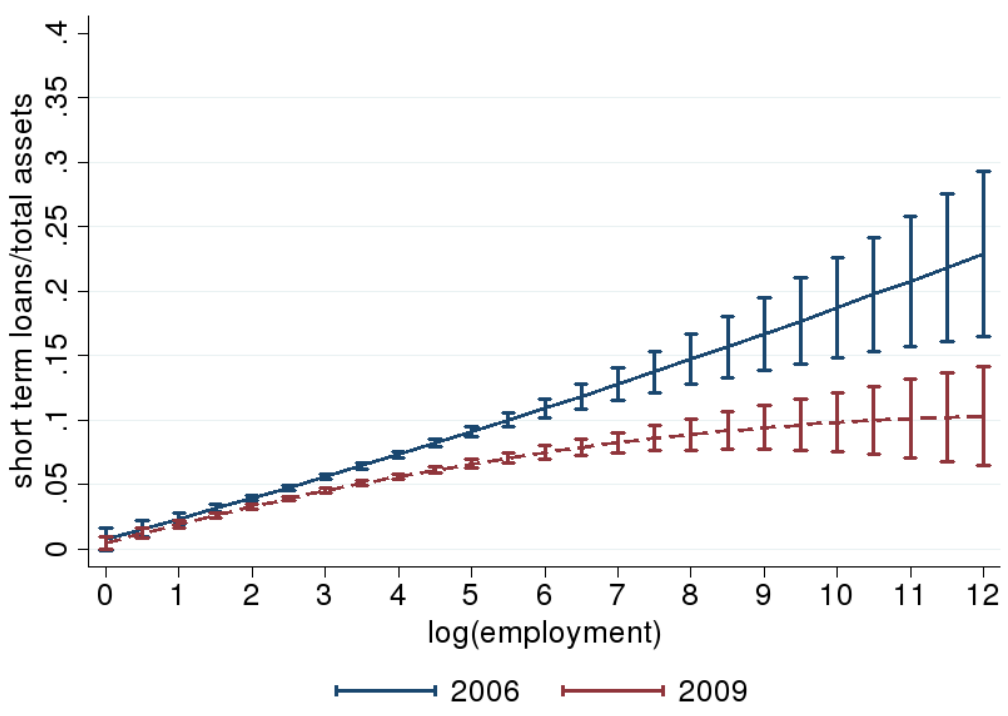

Notes: Use unbalanced sample of private firms separately for 2006 and 2009. The dependent variable is shortterm leverage (STLEV). Each line shows the conditional relationship between leverage, size (measured by log employment), size squared, firm age, collateral, profitability, labor productivity, and a full set of 3-digit industry fixed effects. All observations are weighted to adjust for selection into the LOCUS sample.

Figure 22: Conditional Relationship between short-term leverage and size for public firms (2006 \& 2009)

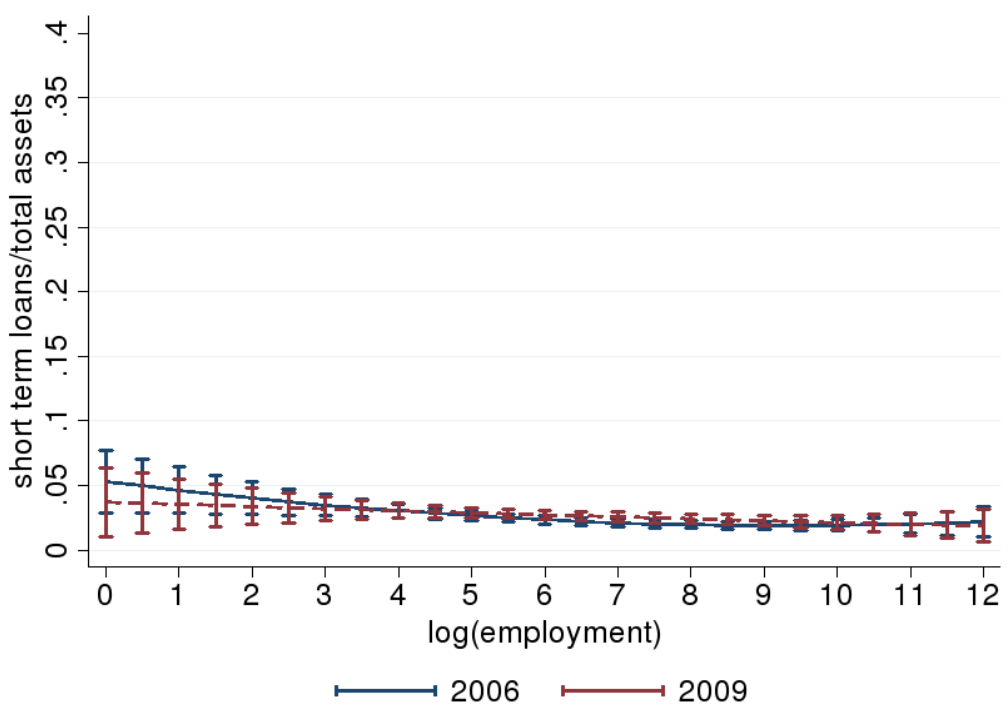

Notes: Use unbalanced sample of public firms separately for 2006 and 2009. The dependent variable is shortterm leverage (STLEV). Each line shows the conditional relationship between leverage, size (measured by log employment), size squared, firm age, collateral, profitability, labor productivity, and a full set of 3-digit industry fixed effects. All observations are weighted to adjust for selection into the LOCUS sample. 